Discussion Paper No. 04-74

\title{
Public Sector Decentralization: \\ Measurement Concepts \\ and Recent International Trends
}

Dan Stegarescu

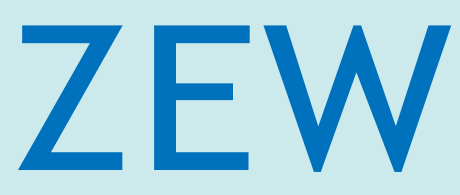

Zentrum für Europäische Wirtschaftsforschung $\mathrm{GmbH}$

Centre for European

Economic Research 
Discussion Paper No. 04-74

\title{
Public Sector Decentralization: Measurement Concepts and Recent International Trends
}

\author{
Dan Stegarescu
}

Download this ZEW Discussion Paper from our ftp server:

\author{
ftp://ftp.zew.de/pub/zew-docs/dp/dp0474.pdf
}

Die Discussion Papers dienen einer möglichst schnellen Verbreitung von neueren Forschungsarbeiten des ZEW. Die Beiträge liegen in alleiniger Verantwortung der Autoren und stellen nicht notwendigerweise die Meinung des ZEW dar.

Discussion Papers are intended to make results of ZEW research promptly available to other economists in order to encourage discussion and suggestions for revisions. The authors are solely responsible for the contents which do not necessarily represent the opinion of the ZEW. 


\section{Nontechnical Summary}

During the last two decades the design of fiscal relations across levels of government has gained increasing importance in public finance literature and practice. In several industrial countries, and especially European Union member countries, competencies and tax-raising powers have been transferred to regional and local levels of government. Also, supranational institutions such as the World Bank, the United Nations or the OECD are actively supporting fiscal decentralization in developing countries and East European transformation countries with the aim of promoting economic and social development, as well as efficiency and transparency in the public sector. At the same time, the interest in the public finance literature in empirical studies of vertical fiscal structures has considerably grown.

Within this context, an important problem encountered in comparing vertical government structures is the appropriate measurement of public sector decentralization. Conventional measures of the degree of fiscal decentralization widely used in the literature relate expenditure and revenue of sub-central government to expenditure and revenue of consolidated general government, as derived from financial statistics. However, without taking into account the vertical structure of decision-making, the degree of decentralization of the public sector tends to be misrepresented and both cross-country comparisons and the description of long-term trends might be seriously distorted. Related to this, erroneous measurement of decentralization may seriously bias particularly the results of empirical studies using such fiscal indicators as explanatory variables and in the end may lead to wrong conclusions.

Given this background, this paper gives a comprehensive analysis of the problems encountered in defining and measuring public sector decentralization and provides an overview of recent international trends. In view of the predominant importance of the provision with own financial resources for sub-national autonomy and the scope of public spending, we focus on the revenue side of fiscal decentralization. Drawing on a recent analytical framework provided by the OECD which classifies taxes according to the degree of local discretion, alternative measures of tax autonomy and revenue decentralization are constructed which take tax-raising powers of sub-central governments into account. The degree of revenue decentralization is then measured by the share of sub-central government revenue from taxes or other resources which are significantly controlled by them in total revenue of consolidated general government.

The new contribution is twofold. First, using data reported by the Revenue Statistics more recent figures on sub-national tax autonomy, as well as on the different indicators of fiscal decentralization are presented for 23 OECD countries, including also countries not considered in the OECD study. Second, taking account of changes in the assignment of decision-making competencies for each tax in the course of time, we investigate the long-term trend providing new time series of annual data on the degree of fiscal decentralization of OECD countries in the time period between 1965 and 2001.

The comparison of figures based on different measurement concepts indicates that common fiscal indicators considerably overestimate the degree of fiscal decentralization or fiscal autonomy in most countries. For countries like Austria or Germany where subcentral governments have only limited autonomy upon taxation a drastically lower degree of decentralization is reported as compared to measures drawing on unadjusted revenue statistics. These findings contradict the common claim that federal countries are more decentralized than unitary countries.

With respect to the development over time, both conventional and improved indicators provide strong evidence for increasing fiscal decentralization in a majority of OECD coun- 
tries during the last three decades. However, no uniform pattern could be determined, several countries also exhibiting tendencies to centralize government activity.

To conclude, conventional expenditure and revenue shares are shown to misrepresent the actual level of fiscal decentralization in a number of countries, therefore being unsuited for cross-country comparisons. On the other side, even though differing considerably in the magnitude, both conventional and adjusted fiscal indicators seem to perform well in describing long-term trends in the public sector. Despite several shortcomings related to aggregation and the use of budgetary data, when adjusted for decision-making structures, expenditure and revenue shares still have the definite advantage of being operational. The new data set provided in this paper therefore might contribute to improving empirical studies on fiscal decentralization. Generally speaking, it seems reasonable to use a set of different indicators instead of a single measure in order to represent the different aspects of decentralization. However, the measure of decentralization to be selected in empirical studies ultimately depends on the specific purpose of the investigation. 


\title{
Public Sector Decentralization: Measurement Concepts And ReCEnt International TREnds ${ }^{\dagger}$
}

\author{
DAN Stegarescu ${ }^{\ddagger}$
}

\begin{abstract}
This paper deals with the problems encountered in defining and measuring the degree of fiscal decentralization. Drawing on a recent analytical framework of the OECD, different measures of fiscal autonomy and revenue decentralization are presented which consider tax-raising powers of sub-central governments. Taking account of changes in the assignment of decision-making competencies in the course of time, new time series of annual data on the degree of fiscal decentralization are provided for 23 OECD countries in the time period between 1965 and 2001. It is shown that common measures usually employed tend to considerably overestimate the extent of fiscal decentralization. Evidence is also provided for increasing fiscal decentralization in a majority of OECD countries during the last three decades.
\end{abstract}

Keywords: Fiscal Decentralization, Measurement of Decentralization, Sub-national Autonomy, Tax Autonomy

JEL: H71, H72, H77

\footnotetext{
†Support by the Priority Programme "Institutional Design of Federal Systems: Theory and Empirical Evidence" (SPP 1142 ) of the German Research Foundation (DFG) is gratefully acknowledged. I would also like to thank Thiess Buettner for helpful comments.

${ }^{\ddagger}$ Centre for European Economic Research, L7,1, D-68161 Mannheim, Germany. Phone: +49 (0)621 1235 167. Fax: +49 (0)621 1235 223. E-mail: stegarescu@zew.de
} 


\section{Introduction}

During the last two decades the design of fiscal relations across levels of government has gained increasing importance in public finance literature and practice. In several industrial countries, and especially European Union member countries, competencies and taxraising powers have been transferred to regional and local levels of government. ${ }^{1}$ Also, supranational institutions such as the World Bank, the United Nations or the OECD are actively supporting fiscal decentralization in developing countries and East European transformation countries with the aim of promoting economic and social development, as well as efficiency and transparency in the public sector. ${ }^{2}$

At the same time, the interest in the public finance literature in empirical studies of vertical fiscal structures has considerably grown. Also trying to detect long-term trends in public sector structures, this empirical literature deals partly with possible determinants of public sector decentralization as derived from the theory of fiscal federalism. ${ }^{3}$ Other studies focus instead on the possible implications of centralization for the size of the public sector, ${ }^{4}$ economic and productivity growth, ${ }^{5}$ or good governance and corruption. ${ }^{6}$

However, an important problem encountered in comparing vertical government structures is the appropriate measurement of public sector decentralization. Despite several shortcomings, the share of sub-national government expenditure or revenue in consolidated general government expenditure or revenue is widely used as a proxy for the degree of decentralization of the public sector. However, Oates (1972), among others, already pointed to the limitations of using budgetary shares. Without taking into account the vertical structure of decision-making, the degree of decentralization of the public sector tends to be misrepresented and both cross-country comparisons and the description of long-term trends might be seriously distorted. It is therefore not obvious that the above mentioned world-wide increase in the sub-national government share of public expenditure and revenue actually reflects fiscal decentralization in terms of the devolution of decision-making powers to lower levels of government.

Related to this, erroneous measurement of decentralization may seriously bias the results of empirical studies and in the end may lead to wrong conclusions. This has been recently confirmed by Ebel and Yilmaz (2003), who replicate previous studies and show that more comprehensive measures of fiscal decentralization actually yield deviating results. Within this context, measurement errors concerning decentralization as the independent variable are more problematic in regression analyses than those concerning decentralization as the dependent variable. ${ }^{7}$ Due to its importance, the measurement of fiscal decentralization has been recently placed on the research agenda of international organizations like the OECD or the World Bank.

Given this background, this paper focuses on the problems encountered in defining and measuring public sector decentralization. The analysis draws on a recent study of the OECD which provides a cross-country comparison of tax-raising autonomy of sub-central governments. Based upon the analytical framework elaborated by the OECD, measures of both fiscal autonomy and revenue decentralization are constructed which consider

\footnotetext{
${ }^{1}$ See, e.g., OECD (2002b, 2003).

${ }^{2}$ See the decentralization project of the World Bank described at www1.worldbank.org/wbiep/decentralization and www.decentralization.org, and, also, OECD (2002a, 2002b) with respect to EU accession countries.

${ }^{3}$ See, e.g., Oates (1972), Wallis and Oates (1988), and, more recently, Panizza (1999), and Schaltegger and Feld (2001).

${ }^{4}$ See the empirical Leviathan literature, e.g., Oates (1985), or Feld et al. (2003), who also provide a survey on this literature.

${ }^{5}$ See, e.g., Davoodi and Zou (1998), Thiessen (2003), or Behnisch et al. (2002).

${ }^{6}$ See, e.g., Arikan (2004), and Fisman and Gatti (2002).

${ }^{7}$ Greene (2000: p.375f), shows that as long as the independent variable is measured properly, measurement error on the dependent variable can be absorbed in the regression disturbance and therefore ignored.
} 
tax-raising powers of sub-central governments. The new contribution is twofold. First, more recent figures on sub-national tax autonomy, as well as on the different indicators of fiscal decentralization are presented for 23 OECD countries. Second, taking account of changes in the assignment of decision-making competencies for each tax in the course of time, we investigate the long-term trend providing new time series of annual data on the degree of fiscal decentralization of OECD countries in the time period between 1965 and 2001.

The analysis shows that common measures usually employed tend to considerably overestimate the extent of fiscal decentralization. For countries like Austria or Germany where sub-central governments have only limited autonomy upon taxation a drastically lower degree of decentralization is reported as compared to measures drawing on unadjusted revenue statistics. This is in accordance with an earlier analysis of Blankart (1999) for Germany. Based on this set of fiscal indicators and the analysis of institutional changes, the development of the vertical government structure in OECD countries is therefore investigated in terms of fiscal autonomy of sub-central government. Though no uniform pattern of development could be determined, evidence is provided for increasing fiscal decentralization in a majority of OECD countries during the last three decades.

The paper proceeds as follows. It starts with a discussion of existing concepts for measuring public sector decentralization. In section 3, then, different indicators of fiscal autonomy and revenue decentralization are derived. Based on this, sections 4 and 5 present new figures on fiscal decentralization for OECD countries and investigate possible long-term trends. Finally, the results are summarized and conclusions are drawn.

\section{Measuring public sector decentralization}

Public sector or fiscal decentralization is commonly associated with the assignment of authority for public functions or finances to lower levels of government. ${ }^{8}$ Due to the complexity of intergovernmental relations, measuring the degree of decentralization, however, is a difficult task which bears many dimensions and which can hardly be accomplished by using a single quantitative measure. ${ }^{9}$

Two important dimensions have to be taken into account when comparing vertical government structures across countries. The first dimension comprises the formal division of functional responsibilities and revenues across levels of government. Within this context, the range and the relative importance of the different functions and revenues assigned to sub-national governments, as well as the extent to which government functions are performed by the private sector determine the degree of fiscal decentralization. ${ }^{10}$

The second and most important dimension concerns the vertical structure of decisionmaking, that is the extent to which decisions regarding functions and resources assigned to lower levels of government are decentralized, too. A system where sub-central levels of government have real autonomy to determine the allocation of their expenditure or to raise own revenue is more decentralized than another system where local or regional government spending and revenue is determined by national legislation, even though the formal assignment of functions or revenues might be the same.

\footnotetext{
${ }^{8}$ The design of fiscal relations across levels of government is to be distinguished from political decentralization, that is the extension of direct or indirect participation of the citizens in public decision-making through referendums or local and regional elections. This form of decentralization does not necessarily imply the transfer of real fiscal responsibilities. Also, the transfer of government functions to the private sector (privatization or contracting out), or, more recently, to the non-profit sector can be interpreted as a distinct form of extensive fiscal decentralization.

${ }^{9}$ For example, Bahl (1986), or, Bird (1986) raise serious doubts regarding this.

${ }^{10}$ See Oates (1972).
} 
The common operational measures of fiscal decentralization used in cross-country comparisons relate sub-central government expenditure or revenue to consolidated general government expenditure or revenue, thus weighting each government activity with the corresponding budgetary share. ${ }^{11}$ This approach to quantifying public sector decentralization, however, suffers from certain limitations. A key methodological problem is associated with the use of aggregate measures. The difficulty consists in distinguishing as to what extent the degree of decentralization reflects the assignment of functions and resources to different levels of government, or, merely, the relative size of sub-central government activities. An increase in the measure of public sector decentralization might be either due to a relative increase in the volume, or, else, in the number of public goods provided by sub-central governments. The first effect merely describes a quantitative effect, a shift in the budgetary shares of the different government functions - in general caused by changing patterns of demand for public goods. In contrast to this, the second effect implies what is generally referred to as true fiscal decentralization, namely the reassignment of government functions in favor of the decentralized provision of public goods.

A second problem is associated with measurement based on fiscal data. It is widely noted that budgetary data in general, and expenditure and revenue shares, in particular, are imperfect indicators of the share of public goods supplied by sub-central governments and the actual degree of decentralization of the public sector. ${ }^{12}$ First of all, the vertical structure of decision-making with regard to public expenditure and revenue is not accurately represented by public finance statistics. These report expenditure and revenue figures at the level of government which ultimately operates or receives them, irrespective of whether it has discretion upon them. Thus, expenditure mandated by the central government or spent on behalf of the central government is reported as subnational expenditure. No distinction is also made between locally determined own taxes, piggybacked or shared taxes, or between conditional and unconditional intergovernmental grants, all being reported as sub-central revenue and grants. It is therefore difficult to interpret the unadjusted sub-national share of expenditure and revenue as reported in financial statistics as an indicator of expenditure and financial autonomy.

Apart from decision-making structures, expenditure and revenue shares also fail to capture the extent of legislative and regulatory activities and other aspects of decentralization which are not directly reflected in fiscal flows. Legislation and regulation is only partly accounted for by expenses for personnel and implementation. ${ }^{13}$ Norms, minimum quality standards, fiscal rules, and other qualitative restrictions imposed by the central government on sub-central levels of government are not reflected in budgetary data, too. Also, coordination among layers of government in the provision of public goods and joint financing are difficult to be taken into account quantitatively. However, it is not obvious whether budgetary statistics will generally tend to under- or overestimate the scope of central government activities, and, thus, the actual degree of fiscal decentralization.

In order to account for the multiple aspects of decentralization, different non-quantitative measures have been proposed in the literature, too. Kaufman (1963) compiles a list of indicators measuring the degree of central government control over sub-national gov-

\footnotetext{
${ }^{11}$ Most empirical studies rely on budgetary data reported by the Government Finance Statistics (GFS) of the International Monetary Fund. See, among others, Levin (1990), Panizza (1999), Thiessen (2003), Miñana (1998), and Rahmann et al. (1994). A description of the data and the methodology can be found in IMF (2001). Some studies also use National Accounts statistics of the UN, such as Oates (1972), and Pommerehne (1977), or of the OECD, such as Patsouratis (1990), or the World Tables reported by the World Bank. These statistics, however, encounter certain limitations and lack especially more recent data. Note also that indicators based solely on public consumption data tend to overestimate the degree of decentralization, since redistributive transfers of central government are not taken into account.

${ }^{12}$ See, e.g., Oates (1972), Levin (1990), Wasylenko (1987), and Kraus (1983) for a comprehensive discussion of the measurement of decentralization. With regard to the limitations of fiscal indicators based on GFS data, see also Ebel and Yilmaz (2003) and the World Bank decentralization project.

${ }^{13}$ See, e.g., Zimmermann (1973).
} 
ernment, mentioning, among others, detailed directives, involvement in the selection of administrative staff, frequency of consultation, and the extent of supervision. Smith (1979) and Bahl (1999) provide comprehensive discussions of factors which together describe the extent of fiscal decentralization, ranging from elected local councils, locally appointed chief officers, institutional provisions, the size and number of sub-national authorities, organizational structures, to fiscal indicators of expenditure, tax-raising and borrowing powers. ${ }^{14}$ For example, the extent to which central government controls the deployment of local administrative personnel, or supervises local government activity, or the right of sub-central governments to appoint judges or to have separate police forces play an important role. Certain studies therefore employed as a non-fiscal indicator of decentralization the ratio of sub-central government employment to total government employment. ${ }^{15}$

Focusing on the size and number of sub-central authorities, the population-normalized number of sub-central jurisdictions, ${ }^{16}$ or even the number of tiers of sub-central government have been occasionally used as alternative measures of decentralization. Larger authorities might be expected to be more autonomous since they have greater political and financial power. On the other hand, the reorganization of local communities into greater local units has a centralizing effect from the point of view of the municipalities involved. ${ }^{17}$ It is also doubtful whether multi-tiered sub-central government systems which, e.g., have an intermediate level - are to be considered more decentralized than single-tiered systems. ${ }^{18}$ On the one hand, in multi-tiered systems it becomes more difficult for the center to control the lower levels of government. From the point of view of the lowest levels of government, however, this implies decisions being taken by a more remote body. Generally speaking, even if providing some information on the number of veto players, indicators of decentralization which compare the sheer number of subcentral jurisdictions with different statutes and degrees of autonomy across countries seem quite problematic and require stringent common definitions.

A few recent approaches take account of vertical decision-making structures in analyzing the degree of fiscal decentralization. Fiscal autonomy of sub-national governments is generally determined by the legislative competencies and the degree of discretion over spending, and especially by tax-raising powers and debt-raising autonomy. A local unit has full autonomy if it is not legally obliged to carry out a function or to raise a certain tax, and if the output, or, respectively, the tax rate and base are not predetermined by another unit of government.

With respect to the supply of public goods, the vertical fiscal imbalance, that is the extent to which sub-central governments rely on central government grants to support their expenditures, is occasionally used as a measure of expenditure autonomy. ${ }^{19}$ A more comprehensive approach would imply breaking down sub-central government expenditure by function and classification according to the degree of local discretion in legislation and execution. ${ }^{20}$ Pola (1999), e.g., carried out detailed surveys on behalf of the European Commission on the framework regulating sub-central government functions in 15 European countries. Sub-central services are classified as being performed exclusively by the local or regional level of government, as being shared between them, or according to

\footnotetext{
${ }^{14}$ See also Treisman (2002).

${ }^{15}$ See, e.g., Arikan (2004). Stephens (1974) constructs a composite index of state centralization containing information on financial responsibility, delivery, and distribution of public personnel between levels of government, in order to divide up government services in central, local, and joint functions.

${ }^{16}$ See, e.g., Oates (1985).

${ }^{17}$ See Sharpe (1979)

${ }^{18}$ See also Oates (1972) on this issue.

${ }^{19}$ See the World Bank decentralization project.

${ }^{20}$ The Council of Europe (1997) provides a comprehensive discussion on different types of powers. See, also, the different contributions in Ter-Minassian (1997), and the decentralization project of the World Bank.
} 
the degree of involvement of central government. ${ }^{21}$ However, no corresponding figures on fiscal decentralization are reported.

Correspondingly, the degree of reliance on revenue from - formally - own resources (own revenue) is quite often used as an indicator of revenue autonomy of sub-central governments. This indicator is defined as the ratio of revenue exclusive of received intergovernmental transfers to total revenue of sub-central governments. ${ }^{22}$ However, it is questionable whether increased reliance on central government grants is to be considered as centralizing in terms of reduced autonomy of sub-central governments.

As mentioned before, these measures of financial autonomy fail to capture decisionmaking structures especially concerning tax revenue assigned to sub-central governments. Pola (1999) provided detailed comparative institutional surveys and also some figures on the degree of self-financing of local and regional governments in EU countries. Blankart (1999) uses the share of general government tax revenue which is determined by central government legislation as a measure of fiscal centralization in order to detect long-term trends in Germany and Switzerland. Aiming at improving the quality of budgetary statistics, the OECD recently provided a comprehensive methodological framework for classifying taxes and tax revenues of sub-central government according to the degree of tax-raising autonomy. Based on the Revenue Statistics, detailed figures are reported for a number of OECD and EU accession countries for 1995/1997 on the revenue structure of different sub-national levels of government. ${ }^{23}$ Drawing on this study, Ebel and Yilmaz (2003) represented fiscal decentralization in terms of the ratio of own taxes which are controlled by sub-central governments to total sub-national revenue.

\section{Indicators of revenue decentralization}

In spite of the problems of aggregation and representation of all aspects of fiscal decentralization discussed above, aggregate measures based on budgetary data which are complemented with information on decision-making powers have the definite advantage of being operational. Even though local discretion on the supply of public goods may play an important role, it is widely accepted that the provision with own financial resources is a crucial condition for sub-national autonomy vis-à-vis the central government and real fiscal decentralization. Both the scope of public spending and the extent of interjurisdictional competition are determined by the degree of sub-national control over its own resources. In view of this, the present paper focuses on the revenue side of fiscal decentralization. ${ }^{24}$

Extending previous approaches to the measurement of sub-national tax autonomy, we provide alternative quantitative measures of both tax autonomy and revenue decentralization which take tax-raising powers of sub-central governments into account. Three aspects seem to be important for the classification of sub-national taxes in decreasing order of fiscal autonomy: legislative competencies to determine tax base and tax rate, the attribution of the tax receipts, and tax administration. One might add the right to choose the tax instrument, distinguishing between compulsory and voluntary taxes, depending on whether a certain tax has to be levied or this rests at the discretion of the local authority. Only taxes which can be chosen independently, and upon which

\footnotetext{
${ }^{21}$ See also Owens and Norregaard (1991) for a similar analysis.

${ }^{22}$ See OECD (1997).

${ }^{23}$ See OECD (1999). Based on a joint initiative together with the World Bank and the Council of Europe, among others, the OECD carries out since 2000 surveys on the design of fiscal systems across levels of government for a group of countries. The first results were presented for six EU-accession countries, see OECD (2002a).

${ }^{24}$ Apart from this, the appropriate quantification of expenditure decentralization involves serious difficulties related to the lack of sufficiently disaggregated data on government functions, and the assessment of local discretion.
} 
sub-central levels of government have own legislative and administrative powers ensure complete financial autonomy.

Concerning the classification of tax revenues according to the degree of control of subcentral governments upon them, Pola (1999), e.g., distinguishes between own (autonomous) taxes, devolved taxes managed by the central government, but the receipts of which accrue to sub-central government, and taxes shared with the central government. The OECD approach mentioned above provides a more detailed classification of tax autonomy:

Classification of taxes (in decreasing order of control over revenue sources)

\begin{tabular}{l|l}
\hline \hline (a) & sub-central government (SCG) determines tax rate and tax base \\
(b) & SCG determines tax rate only \\
(c) & SCG determines tax base only \\
(d) & tax sharing: \\
(d.1) & SCG determines revenue-split \\
(d.2) & revenue-split only changed with consent of SCG \\
(d.3) & revenue-split unilaterally changed by centr. gov. (CG) (fixed in legislation) \\
(d.4) & revenue-split unilaterally changed by CG (in annual budgetary process) \\
(e) & CG determines tax rate and tax base \\
\hline \multicolumn{2}{l}{ Source: OECD (1999). } \\
\hline
\end{tabular}

In cases (a) to (c), which are referred to as "own taxes", sub-central government has total or significant control over its taxes, whereas in case of the revenue sharing categories (d.1) to (d.2) it has some limited control through mechanisms of co-decision. For tax revenue categories (d.3) to (e) sub-central government has no control at all, these resembling to unconditional general purpose grants. Based on the 4-digit classification of taxes by the base of the tax reported in the annual Revenue Statistics, ${ }^{25}$ the OECD survey classifies each tax, the receipts of which are assigned to sub-central governments, according to the degree of decision-making autonomy as presented above. The taxes are subsequently weighted with the corresponding share in total tax revenue of sub-central governments.

In the following, we apply this methodology with some minor changes to derive a set of different indicators of revenue decentralization. An aggregate measure of tax autonomy of sub-central governments can be derived either by using a qualitative scale for the different tax categories (a) to (e) which reflects the decreasing extent of discretion, or, simply by summing up the different taxes which only accrue to sub-central levels of government (own taxes) and which are significantly controlled by them, weighted with the corresponding shares in their total tax revenue. Even if no distinction is made between the different types of autonomous taxes, the last method avoids any problems of arbitrary assessment and is therefore preferred here. A value of $100 \%$ then indicates full autonomy ${ }^{26}$ The degree of tax autonomy accounting for autonomous own taxes is thus defined as:

$$
\text { TAut1 }=\frac{\text { SCG own tax revenue }(\mathrm{a}) \text { to }(\mathrm{c})}{\text { SCG total tax revenue }}
$$

\footnotetext{
${ }^{25}$ Note that the Revenue Statistics attributes the following tax revenues to sub-national governments: local taxes collected by them, surcharges on national taxes, and automatically received shares of taxes collected by the central government in their territory.

${ }^{26}$ Note that this measure is slightly different from the tax autonomy indicator presented in Ebel and Yilmaz (2003) which relates own taxes to total sub-national revenues.
} 
Since especially in federal or quasi-federal countries like Austria, Germany, Spain, Switzerland, and, most recently, Belgium, regional or state governments have some influence on the revenue-split of certain shared taxes, one might consider additionally revenue from shared taxes as partly autonomous, too. Unlike intergovernmental transfers, tax revenuesharing is in general fixed by law or constitution and therefore has a more permanent nature. This alternative indicator then denotes the extent to which sub-central governments (SCG) have full or at least some limited control over their tax revenues:

$$
\text { TAut } 2=\frac{\text { SCG own tax revenue }(\mathrm{a}) \text { to }(\mathrm{c})+\text { shared tax revenue }(\mathrm{d} .1) \text { to }(\mathrm{d} .2)}{\text { SCG total tax revenue }}
$$

According to the discussion in section2, decision-making autonomy represents only one dimension of decentralization. The scope of sub-central activity has to be taken into account, too. Therefore, the receipts from the different taxes of sub-central governments $(\mathrm{SCG})^{27}$ are classified according to the degree of decision-making autonomy and set in relation to tax revenue of consolidated general government $(\mathrm{GG})$ in order to measure the degree of tax decentralization. In the case of federal states where local taxes or regional/local revenue-sharing are determined by regional or state governments, these are classified as autonomous taxes, since we now focus on the degree of fiscal autonomy vis-à-vis the central government. In doing so, local governments are treated as an integral part of the intermediate level of government.

The measures of tax revenue decentralization which account for autonomous own taxes of sub-central governments only (TDec1), or additionally for autonomous shared taxes (TDec2), too, are presented below and compared to the conventional measure of decentralization based on total sub-national tax revenue as reported in financial statistics (TDec3):

$$
\text { TDec1 }=\frac{\text { SCG own tax revenue }(\mathrm{a}) \text { to }(\mathrm{c})}{\text { GG total tax revenue }}
$$

$$
\mathrm{TDec} 2=\frac{\text { SCG own tax revenue }(\mathrm{a}) \text { to }(\mathrm{c})+\text { shared tax revenue }(\mathrm{d} .1) \text { to }(\mathrm{d} .2)}{\text { GG total tax revenue }}
$$

$$
\text { TDec3 }=\frac{\text { SCG total tax revenue }(\mathrm{a}) \text { to }(\mathrm{e})}{\text { GG total tax revenue }}
$$

Extending the analysis to all sources of public revenue, non-tax revenue, such as user charges or operational surplus of public enterprises, and capital revenue could be classified as own autonomous revenue. ${ }^{28}$ From the point of view of expenditure autonomy, general purpose and unconditional specific purpose grants attach no constraints on how the grants are spent, and might therefore be classified as own revenues of sub-national governments. ${ }^{29}$ In contrast to this, conditional specific purpose grants are earmarked for particular purposes and therefore offer only little discretion concerning their use. However, with respect to financial autonomy, it is irrelevant whether the funds can be spent

\footnotetext{
${ }^{27}$ Note that regional and local levels of government are consolidated now, local taxes being classified as described below.

${ }^{28}$ Due to the complexity of this area, possible limitations imposed by central legislation on the levying of user charges are not taken into account here.

${ }^{29}$ See, e.g., Wasylenko (1987), and Ebel and Yilmaz (2003).
} 
independently, but instead whether the revenues are generated autonomously by subcentral governments. In contrast to revenue-sharing, general purpose grants are usually not fixed in legislation, but unilaterally during the annual budgetary process, therefore remaining at the discretion of the central government and depending on its financial situation. Since sub-central governments have no control over the amount and structure of these revenues, it seems reasonable to classify all types of intergovernmental grants as non-autonomous revenue corresponding to the OECD category (e) of tax autonomy. ${ }^{30}$

For reasons of aggregation across different levels of government, the corresponding degree of revenue decentralization is then derived excluding intergovernmental grants received from other levels of government. Again, apart from own non-tax and capital revenue, we consider alternatively only autonomous own taxes of sub-central governments $(R D e c 1)$, autonomous own and shared taxes (RDec2), and total sub-national tax revenue as reported in financial statistics $(R D e c 3)$ :

$$
\text { RDec1 }=\frac{\text { SCG own tax rev. (a) to }(\mathrm{c})+\text { non-tax \& capital rev. }}{\text { GG total tax rev. }+ \text { non-tax \& capital rev. }}
$$

$\mathrm{RDec} 2=\frac{\text { SCG own tax } \mathrm{r} .(\mathrm{a}) \text { to }(\mathrm{c})+\text { sh. tax } \mathrm{r} .(\mathrm{d} .1) \text { to }(\mathrm{d} .2)+\text { non-tax } \& \text { cap. } \mathrm{r} .}{\text { GG total tax rev. }+ \text { non-tax } \& \text { capital rev. }}$

$$
\text { RDec3 }=\frac{\text { SCG total tax rev. (a) to }(\mathrm{e})+\text { non-tax \& capital rev. }}{\text { GG total tax rev. }+ \text { non-tax \& capital rev. }}
$$

Further possible extensions of the OECD approach might imply the differentiation of autonomous taxes in view of considering the degree of discretion on choosing the taxing instruments (compulsory vs. voluntary taxes), the limits imposed on setting tax rates or tax bases, or the distinction between own taxes and taxes levied as a surcharge on national taxes (piggybacked taxes). ${ }^{31}$ Since any attempt to qualify the different types of autonomous taxes or other similar revenue sources by means of rankings bears serious problems of arbitrariness, we refrain from going into further detail here. Particularly the share of autonomous own tax, and, respectively, own revenue of sub-central governments, in total tax, and, respectively, total revenue of consolidated general government (indicators TDec1 and RDec1) provide fairly good approximations of the degree of decentralization. Since these two indicators are expected to best reflect real decision-making powers, the investigation below will particularly focus on them. However, as already pointed to in section 2, the general question still arises whether countries with an intermediate level of government are to be considered as more decentralized than countries without such a level, even if the degree of tax revenue decentralization might be the same.

\footnotetext{
${ }^{30}$ This is also in accordance with the OECD taxonomy which does not take into account the degree of discretion over the use of shared or ceded tax receipts. Of course, this might be different in federal or quasi-federal states where sub-central governments participate in decision-making upon the allocation of grants.

${ }^{31}$ See also OECD (1999) for a discussion.
} 


\section{A current overview of OECD countries}

Using the latest data reported in the Revenue Statistics and taking account of the legal assignment of legislative powers for each tax actually in force during the period investigated, we provide an update of the OECD (1999) study concerning the classification of taxes of sub-central governments in terms of tax-raising autonomy. For this purpose each local tax has been investigated on an annual basis in terms of decision-making powers of sub-national government. The sample consists of 23 OECD countries, including also new countries not considered in the OECD survey. ${ }^{32}$ Going beyond the OECD approach, current figures on revenue autonomy of sub-central governments and fiscal decentralization are derived applying the different measurement concepts described above.

For reasons of consistency and comparability, the degree of tax autonomy is only derived according to the provisions fixed in legislation, and, particularly, the extent of participation of sub-central governments in decision-making. Therefore, the actual implementation is not taken into account, focusing only on the potential degree of fiscal autonomy. ${ }^{33}$ As far as possible, the different tiers of sub-national government are dealt with separately. In doing so, one must take into account that especially in federal countries local government taxes are regulated by regional or state legislation, without implication of the central government. Therefore, own local taxes and taxes shared with regional or state governments have to be classified in accordance with the degree of control exercised by the upper sub-central level of government.

To begin with, Table 1 presents more recent figures for the classification of different taxes of sub-central governments according to the scheme proposed by the OECD. The first three columns indicate a very high degree of fiscal autonomy in most OECD countries, sub-central governments controlling nearly all tax revenue accruing to them. ${ }^{34}$ This is especially the case for state or local governments in federal states like Australia, ${ }^{35}$ Canada, Switzerland, or the USA, as well as for local governments in unitary states like the Scandinavian countries, Netherlands, or the UK. In contrast to this, state, and, to a lesser extent, local governments in Austria and Germany barely enjoy true fiscal autonomy. Only when taking into consideration the participation in decision-making on the allocation of shared taxes, a certain degree of autonomy can be ascribed to these countries. This provides some quantitative evidence for the wide-spread view in public finance literature which describes both countries as centralized federal states. Local governments in Greece, Ireland and Portugal are also found to rely heavily on nonautonomous revenue.

In order to compare the degree of sub-national fiscal autonomy across countries, Figure 1 illustrates the two indicators of tax autonomy for consolidated sub-central levels of government. Once again, sub-central governments in Austria and Germany are shown to have the lowest degree of real tax autonomy among the OECD countries analyzed, only comparable to Greece.

Figure 2 presents the different measures of tax decentralization for the OECD countries. In terms of real fiscal autonomy (indicator TDec1), Greece, Ireland, Austria, Portugal,

\footnotetext{
${ }^{32}$ The focus is on developed economies with long-standing democratic traditions for which long time series are available. Therefore certain countries reported in the OECD survey are not considered here. Instead of this, new countries have been included in this study: Australia, Canada, France, Greece, Ireland, Italy, Luxembourg, and the United States.

${ }^{33}$ Note that our classification of certain taxes differs from the OECD survey. Just to give an example, in Norway local governments choose de facto the same maximum local income tax rate, although, in principle, variation is allowed. Whereas the OECD study therefore classifies this tax as a shared tax the revenue-split of which is determined unilaterally by the central government (d.4), we consider this tax as autonomous (b).

${ }^{34}$ However, note that for certain countries the data allow no distinction between the different tiers of sub-central government.

${ }^{35}$ Yet, Australian states themselves are highly centralized, granting no fiscal autonomy to their municipalities.
} 
Table 1: Taxes of sub-central levels of government according to the degree of autonomy, 2001

\begin{tabular}{|c|c|c|c|c|c|c|c|c|c|}
\hline \multirow{2}{*}{$\begin{array}{l}\text { Country } \\
\text { AUS }\end{array}$} & Lev. gov. & (a) & (b) & (c) & $\overline{(\mathrm{d} .1)}$ & $\begin{array}{l}(\mathrm{d} .2) \\
\end{array}$ & $\overline{(\mathrm{d} .3)}$ & (d.4) & $\overline{(\mathrm{e})}$ \\
\hline & $\begin{array}{l}\text { Regional } \\
\text { Local }\end{array}$ & 100.0 & & & & & & & 100.0 \\
\hline AUT & $\begin{array}{l}\text { Regional } \\
\text { Local }\end{array}$ & 5.2 & $\begin{array}{c}2.4 \\
11.2\end{array}$ & & & $\begin{array}{l}97.6 \\
83.6\end{array}$ & & & \\
\hline BEL & Reg./Loc. ${ }^{a}$ & 3.7 & 51.3 & & & 44.4 & 0.3 & 0.3 & \\
\hline \multirow[t]{2}{*}{ CAN } & Regional & 60.0 & 38.7 & & 1.3 & & & & \\
\hline & Local & 7.9 & 87.3 & & & & 4.8 & & \\
\hline DEN & Local & & 94.4 & & & & 3.5 & & 2.1 \\
\hline FIN & Reg./Loc. ${ }^{a}$ & 0.0 & 83.0 & & & & 17.0 & & \\
\hline FRA & Reg./Loc. ${ }^{a}$ & & 99.0 & & & & 0.2 & & 0.8 \\
\hline GER & $\begin{array}{l}\text { Regional } \\
\text { Local }\end{array}$ & 1.0 & 55.3 & & & $\begin{array}{c}100.0 \\
43.6\end{array}$ & & & \\
\hline GRE & Local & & 13.9 & & & & 41.9 & & 44.2 \\
\hline ICL & Local & 7.2 & 92.8 & & & & & & \\
\hline IRL & Local & & 55.1 & & & & & & 44.9 \\
\hline ITA & Reg./Loc. ${ }^{a}$ & & 90.6 & & & & 3.3 & & 6.1 \\
\hline JAP & Local & 0.1 & 91.1 & & & & & & 8.8 \\
\hline LUX & Local & 0.2 & 99.4 & & & & 0.4 & & \\
\hline \multirow[t]{2}{*}{ NED } & Regional & & 100.0 & & & & & & \\
\hline & Local & 3.3 & 96.7 & & & & & & \\
\hline NEZ & Reg./Loc. ${ }^{a}$ & 98.8 & & & & & & & 1.2 \\
\hline NOR & Local & & 98.2 & & & & 1.8 & & \\
\hline POR & Reg./Loc. ${ }^{a}$ & 6.7 & 29.9 & & & & 13.9 & & 49.5 \\
\hline SPA & Reg./Loc. ${ }^{a}$ & 51.3 & 35.0 & & & 5.6 & 8.1 & & \\
\hline SWE & Reg./Loc. ${ }^{a}$ & 0.0 & 100.0 & & & & & & \\
\hline \multirow[t]{2}{*}{ SWI } & Regional & 88.4 & & & 5.5 & 6.1 & & & \\
\hline & Local & & 100.0 & & & & & & \\
\hline UK & Local & & 100.0 & & & & & & \\
\hline \multirow[t]{2}{*}{ USA } & Regional & 100.0 & & & & & & & \\
\hline & Local & 71.4 & 28.6 & & & & & & \\
\hline
\end{tabular}

Note: As per cent of total tax revenue of sub-central government. In case of various regional or local tiers of government, these are consolidated at each corresponding level of government. ${ }^{a}$ Due to problems of data identification, local and regional level of government are consolidated. See Table 7 in the Appendix for an overview of the government structures. Source for data: OECD, Revenue Statistics, latest year available. Source for tax classification: see Table 5.

and the United Kingdom exhibit the lowest degrees of decentralization with values below $5 \%$. Within this context note that the scope of sub-central government activity plays an important role. Although local governments in certain countries like Netherlands, New Zealand, or the UK have maximum levels of fiscal autonomy, their share in total public sector activity is rather small. As expected, federal states like Switzerland, Canada, and the USA belong to the most decentralized countries. Surprisingly enough, however, unitary countries like Sweden, Denmark, and Japan exhibit very high degrees of tax decentralization, thus contradicting, at least in terms of budgets, the presumption that single-tiered or unitary systems are more centralized than multi-tiered or federal systems.

The situation changes considerably for countries like Austria, Belgium, or Germany, when shared taxes co-determined by sub-central levels of government are further taken into account (indicator TDec2). Considerable differences between the conventional measure of decentralization using total tax revenue of sub-central governments (indicator TDec3) and the measure accounting for fiscal autonomy are also found for Finland, Greece, Ireland, Italy, Japan, Portugal, and Spain. This picture clearly illustrates that 


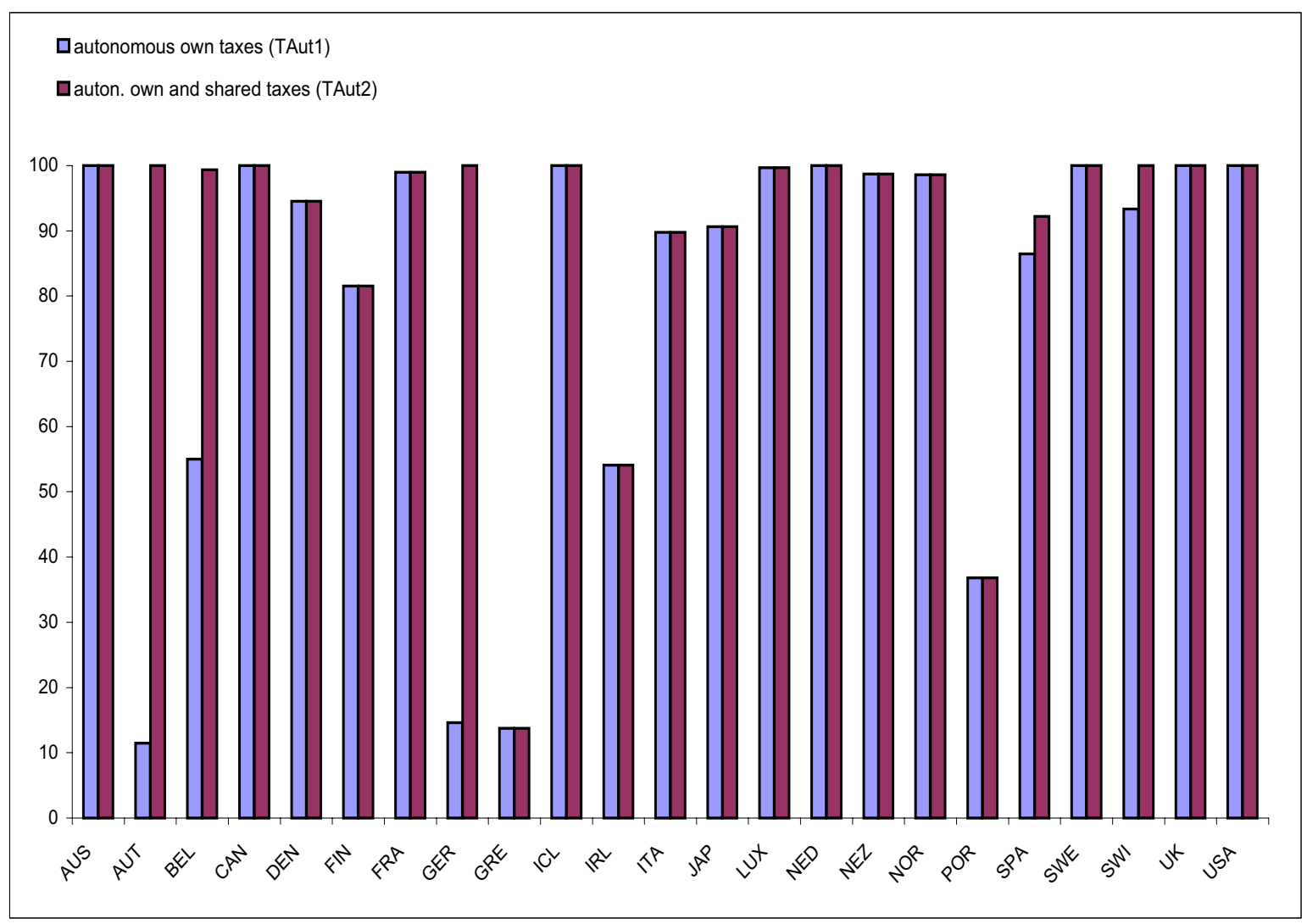

Note: Local and regional government are consolidated. Three-year-average. See the text for a description of the two indicators. Source: See Table 5.

conventional revenue shares reflect the degree of fiscal decentralization correctly only if sub-central governments have entire control upon their revenue, as is the case, e.g., in the USA, Canada, or Sweden. ${ }^{36}$ For most countries, however, such as particularly Austria, Belgium, Germany, or Portugal the degree of real fiscal decentralization is clearly overestimated by the indicators commonly used in empirical studies.

With respect to total revenue of sub-central governments, the results are quite similar. ${ }^{37}$ Note, however, that with few exceptions the degree of revenue decentralization is generally higher as compared to tax revenue. Particularly for Australia, Austria, Germany, Ireland, Netherlands, and the USA this reflects significant reliance of local governments on non-tax revenue such as user charges.

These approaches to quantifying tax-raising autonomy still suffer, however, from certain limitations related to differences between practice and legal provisions, and to problems of data disaggregation. Concerning the latter aspect, for certain countries the data allow no distinction between regional and local government, or between different tiers within the same level of government. ${ }^{38}$ Also, the 4-digit tax classification of the Revenue Statistics is often not detailed enough. The classification of some taxes according to

\footnotetext{
${ }^{36}$ Ebel and Yilmaz (2003) also note that misrepresentation of the degree of fiscal decentralization might be more serious for developing or transition countries, where local governments have no discretion over revenue and expenditure at all.

${ }^{37}$ See Table 9 in the appendix.

${ }^{38}$ Note that the OECD (1999) survey reports data for the different levels of sub-central government, however, only for 1995.
} 


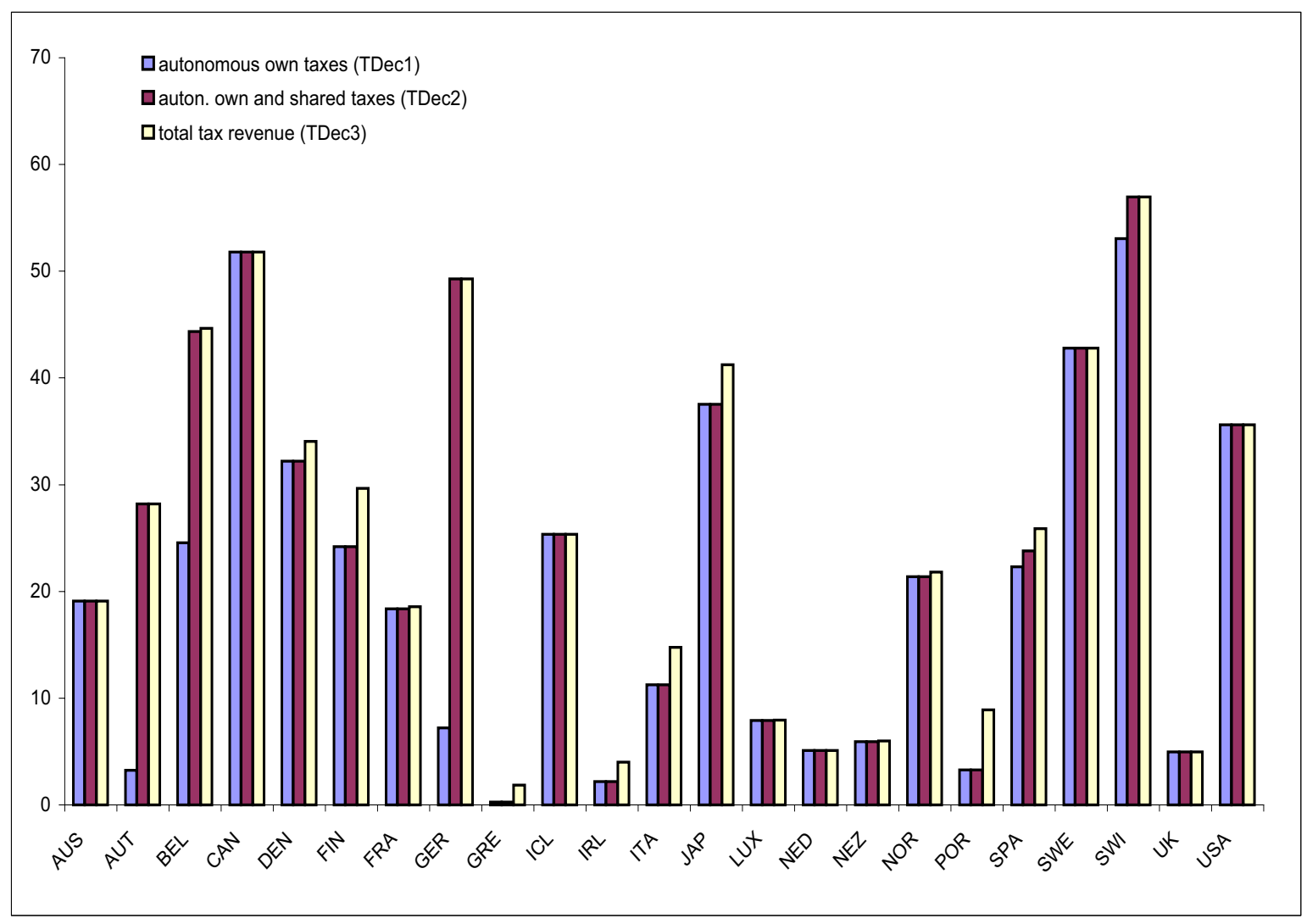

Note: See the text for a description of the three indicators. Three-year-average. Source: See Tables 5 and 6.

the degree of autonomy might therefore be partly erroneous. Another major problem is related to the horizontal aggregation of data across jurisdictions belonging to the same level of government, but which are vested with different competencies. ${ }^{39}$ This is particularly the case of the regions with special status in France, Italy and Spain, or the home rule territorial arrangements for the Portuguese islands of Madeira and Azores, and for Scotland, Wales and Northern Ireland in the United Kingdom. Furthermore, especially in federal states, where the competencies of local governments are determined by state legislation or constitution (e.g., USA, Canada, Switzerland, Australia), there are considerable inter-state differences in the degree of tax autonomy granted to local governments. A more correct measure might therefore consider the horizontal disaggregation of tax revenue data by jurisdictions. However, due to the lack of appropriate data, this is not feasible in the present analysis. Despite these limitations, the indicators accounting for fiscal autonomy presented above definitively contribute to improving the measurement of fiscal decentralization. ${ }^{40}$

Table 2 finally summarizes the different measures of fiscal decentralization. Conventional measures of expenditure decentralization, and of tax and own revenue decentralization are reported in the first two columns, and, respectively, in the columns (5) and (7). GFS data from the IMF are used to calculate the degree of expenditure decentralization.

\footnotetext{
${ }^{39}$ This is the case referred to as asymmetric fiscal decentralization in section 2 . See, also, IMF (2001) with respect to problems of horizontal aggregation.

${ }^{40}$ Note that in the present sample the coefficient of correlation between the degree of tax autonomy (TAut 1 ) and the corresponding degree of tax decentralization including only autonomous taxes (TDec1) is 0.50 , as compared to 0.14 when considering the common measure of tax decentralization (TDec3).
} 
Table 2: Summary of different indicators of fiscal decentralization, OECD countries, 1996-2001

\begin{tabular}{|c|c|c|c|c|c|c|c|}
\hline & EDec1 (1) & EDec2 (2) & TDec1 (3) & TDec2 (4) & TDec3 (5) & RDec1 (6) & RDec3 (7) \\
\hline AUS & 48.3 & 31.6 & 20.9 & 20.9 & 20.9 & 31.6 & 31.6 \\
\hline AUT & 47.5 & 33.8 & 3.5 & 28.7 & 28.7 & 14.1 & 34.7 \\
\hline BEL & 39.5 & 33.8 & 24.2 & 44.2 & 44.5 & 24.7 & 44.0 \\
\hline $\mathrm{CAN}$ & 63.7 & 56.5 & 52.4 & 52.4 & 52.4 & 56.7 & 56.7 \\
\hline $\mathrm{DEN}$ & 59.9 & 36.1 & 31.8 & 31.8 & 33.6 & 32.3 & 33.8 \\
\hline FIN & 45.2 & 34.7 & 25.3 & 25.3 & 30.4 & 31.3 & 35.1 \\
\hline FRA & 32.2 & 21.5 & 19.2 & 19.2 & 19.4 & 23.1 & 23.2 \\
\hline GER & 64.6 & 60.2 & 7.3 & 49.6 & 49.6 & 20.8 & 50.1 \\
\hline GRE & $5.6^{a}$ & $3.5^{a}$ & 0.2 & 0.2 & 2.0 & & \\
\hline ICL & 33.7 & 30.1 & 24.7 & 24.7 & 24.7 & 25.4 & 25.4 \\
\hline IRL & 28.4 & 7.4 & 2.3 & 2.3 & 3.9 & 9.4 & 10.3 \\
\hline ITA & 36.3 & 17.2 & 8.6 & 8.6 & 13.1 & 9.9 & 15.0 \\
\hline JAP & 62.8 & 27.6 & 36.7 & 36.7 & 40.5 & & \\
\hline LUX & 27.6 & 17.5 & 8.3 & 8.3 & 8.3 & 13.3 & 13.3 \\
\hline NED & 45.9 & 13.7 & 5.1 & 5.1 & 5.1 & 14.7 & 14.7 \\
\hline NEZ & 11.1 & 10.0 & 5.7 & 5.7 & 5.8 & 9.2 & 9.3 \\
\hline NOR & $46.1^{b}$ & $32.7^{b}$ & 22.6 & 22.6 & 23.0 & 24.9 & 25.2 \\
\hline POR & 13.7 & 9.0 & 3.1 & 3.1 & 8.4 & 6.3 & 10.5 \\
\hline SPA & 63.4 & 30.8 & 20.8 & 23.2 & 25.2 & 20.7 & 25.8 \\
\hline SWE & 42.0 & 34.8 & 43.7 & 43.7 & 43.7 & 40.0 & 40.0 \\
\hline SWI & 78.2 & 62.2 & 53.9 & 57.8 & 57.8 & 60.7 & 63.6 \\
\hline UK & $31.6^{b}$ & $19.3^{b}$ & 4.9 & 4.9 & 4.9 & 9.2 & 9.2 \\
\hline USA & 60.2 & 49.9 & 36.3 & 36.3 & 36.3 & 46.3 & 46.3 \\
\hline
\end{tabular}

Note: (1)-(2) Total expenditure and lending minus repayments of sub-central government in \% of consolidated general government expenditure, without social security and EU payments; for JAP only current expenditure (revenue); (1) direct expenditure, excluding transfers to other levels of government; (2) total expenditure, including transfers to other levels of government net of received transfers. (3)-(5) Tax revenue of sub-central government in \% of consolidated general government tax revenue, without social security and EU payments: (3) autonomous own taxes, (4) autonomous own and shared taxes, (5) total tax revenue of sub-central governments. (6)-(7) Own revenue of sub-central government, excluding received transfers from other levels of government, in \% of consolidated general government revenue, without social security and EU payments: (6) autonomous own taxes and own non-tax and capital revenue, (7) total own tax, non-tax and capital revenue of sub-central government. Six-year-averages, ${ }^{a}$ 1981-82, ${ }^{b}$ 1988-90. Source: for (1)-(2) IMF, Government Finance Statistical Yearbook (except for: BEL - Banque Nationale de Belgique, JAP - OECD, National Accounts); for (3)-(7) OECD, Revenue Statistics. Own calculations.

Problems regarding the appropriate treatment of intergovernmental transfers when aggregating expenditure data across different levels of government are taken into account by attributing intergovernmental transfers to the recipient, and, alternatively, to the granting level of government. ${ }^{41}$ In the first case, intergovernmental transfers from lower levels of government are attributed to the central government, the degree of decentralization thus reporting only amounts spent or administered directly by the sub-central level of government (direct expenditure, indicator EDec1). In the second case, sub-central government spending includes intergovernmental expenditure, too, but excludes intergovernmental revenue from central government (total expenditure, indicator EDec2). Then, all public expenses financed from formally own resources are taken into account. This seems particularly reasonable when the grantor prescribes the use of these funds (conditional grants). However, in case of unconditional grants, it would be more appropriate to attribute these funds to the recipient.

The figures indicate large disparities between the different indicators. The degree of decentralization is in general found to be lower for revenue than for expenditure accord-

\footnotetext{
${ }^{41}$ See Oates (1972), Levin (1990), and Kraus (1983).
} 
ing to the unadjusted indicators, which indicates positive net vertical transfers to the sub-central levels of government. As expected, the sub-national share of public spending seems to be lower for total expenditure (EDec2) than for direct expenditure (EDec1), since received intergovernmental grants are deducted. In most cases, own revenue figures (RDec3) prove to be a good approximation of total expenditure, which is due to the fact that total expenditure indicate the level of government financing the public functions. Just as with tax revenue, both federal countries like Canada, Switzerland, or the USA, and unitary countries like Denmark, Japan, or Spain have the highest degrees of decentralization in terms of direct expenditure. Note, also, that Germany belongs after Switzerland to the most decentralized countries according to figures not accounting for decision-making structures. As can be seen again, the differences between indicators taking the extent of tax autonomy into account (especially TDec1 and RDec1), and conventional revenue measures are quite considerable in several cases.

\section{Decentralization trends in OECD countries}

In the following, the long-term development of the vertical government structure of OECD countries is analyzed in order to detect possible decentralization trends. Using annual data reported by the IMF and the OECD, both conventional measures of decentralization and the indicators accounting for decision-making competencies are employed. In case of the latter, changes in the assignment of tax-raising powers in the course of time are explicitly taken into account.

The most prominent examples of fiscal decentralization during the last three decades are certainly Belgium and Spain. ${ }^{42}$ In Belgium the process of decentralization started in 1970 with the creation of regions and communities and their subsequent endowment with expenditure and tax-raising competences in the 1980s, and culminated in the creation of a federal state in 1994. After the end of the Franco regime, local autonomy has been (re-)established in Spain and legislative powers and taxes have been transferred particularly to the newly created autonomous regions. Yet, the process of devolution is still open in both countries. Similarly, in Canada increasing separatism has led to the strengthening of the autonomy of Québec. Apart from these examples, devolution of expenditure and tax-raising powers particularly to regional governments can be observed in France, Italy, Denmark, Portugal and Greece. Most recently, in the United Kingdom a Scottish and a Welsh parliament have been created and endowed with limited legislative and administrative autonomy. And even in federal countries like Germany or Austria decentralization of responsibilities is currently gaining momentum in the public discussion.

Table 3 presents a quantitative overview of the development according to the conventional fiscal indicators described in section 2 and presented in Table 2. Drawing on budgetary data for 23 OECD countries reported by the GFS of the IMF for the period 1970 to $2001,{ }^{43}$ consolidated sub-central government expenditure and revenue are set in relation to consolidated general government expenditure, and, respectively, revenue applying the concepts described above. According to the financial statistics, social security payments and contributions are considered first as part of consolidated central government. Endowed with own budgets and decision-making autonomy, these corporations have to be considered as a distinct centralized level of government, since services are provided on a nationwide scale. ${ }^{44}$

\footnotetext{
${ }^{42} \mathrm{~A}$ broad descriptive overview of the most significant institutional changes with respect to both expenditure and tax-raising competencies is provided in the appendix.

${ }^{43}$ Note that the time periods available for the individual countries are of different length.

${ }^{44}$ Note that extra-budgetary accounts are included in consolidated central government, too.
} 
Table 3: Degree of fiscal decentralization (incl. social security), OECD countries, 1970-2001

\begin{tabular}{l|cc|cc|cc}
\hline \hline Country & \multicolumn{2}{|c|}{ Direct expenditure (1) } & \multicolumn{2}{|c|}{ Total expenditure $(2)$} & \multicolumn{2}{c}{ Own revenue (3) } \\
& $1970-75$ & $1996-2001$ & $1970-75$ & $1996-2001$ & $1970-75$ & $1996-2001$ \\
\hline AUS & 49.3 & 48.3 & 27.4 & 31.6 & 24.0 & 32.9 \\
AUT & 33.1 & 32.0 & 25.2 & 22.8 & 27.2 & 24.9 \\
BEL & 14.6 & 27.8 & 7.7 & 25.2 & 7.5 & 26.1 \\
CAN & 57.7 & 60.0 & 48.3 & 53.2 & 47.8 & 52.4 \\
DEN & 59.2 & 55.6 & 29.4 & 33.5 & 29.5 & 32.4 \\
FIN & 36.8 & 38.3 & 26.3 & 29.4 & 27.0 & 31.1 \\
FRA & 17.5 & 18.2 & 10.8 & 12.1 & 8.7 & 13.5 \\
GER & 44.1 & 36.1 & 39.7 & 33.4 & 37.4 & 32.7 \\
GRE & 3.9 & & 3.7 & & 3.5 & \\
ICL & 17.7 & 28.2 & 17.8 & 25.1 & 18.9 & 23.8 \\
IRL & 28.3 & 24.9 & 16.5 & 6.6 & 14.1 & 7.0 \\
ITA & 17.8 & 24.9 & 7.9 & 11.7 & 5.5 & 11.6 \\
JAP & 48.4 & 35.8 & 22.9 & 18.4 & 25.7 & 23.5 \\
LUX & 16.4 & 15.5 & 8.8 & 10.0 & 8.3 & 10.0 \\
NED & 33.4 & 28.3 & 7.4 & 8.5 & 3.8 & 10.3 \\
NEZ & $12.5^{a}$ & 11.1 & 10.4 & 10.0 & $11.3^{a}$ & 10.1 \\
NOR & 36.9 & 34.1 & 32.7 & 21.8 & 32.2 & 20.9 \\
POR & 6.8 & 10.1 & 3.4 & 6.6 & 4.2 & 6.4 \\
SPA & 9.8 & 35.8 & 5.4 & 17.4 & 5.1 & 18.1 \\
SWE & 43.5 & 36.3 & 32.5 & 30.1 & 31.9 & 29.7 \\
SWI & 57.8 & 49.6 & 49.9 & 44.0 & 47.3 & 43.5 \\
UK & 32.1 & 21.9 & 19.6 & 7.2 & 15.7 & 7.8 \\
USA & 44.4 & 47.6 & 35.7 & 39.5 & 39.3 & 41.6 \\
\hline Median ${ }^{b}:$ & & & & & & \\
OECD & 33.2 & 33.1 & 21.3 & 22.3 & 21.5 & 23.7 \\
EU15 & 30.2 & 28.1 & 13.7 & 14.8 & 11.4 & 15.8 \\
\hline
\end{tabular}

Note: Total expenditure and lending minus repayments (total revenue and grants) of sub-central government in $\%$ of consolidated general government expenditure (revenue), without EU payments; for JAP only current expenditure (revenue). Six-year-averages, ${ }^{a} 1978-80,{ }^{b}$ without GRE. (1) expenditure excluding transfers to other levels of government (indicator EDec1); (2) expenditure including transfers to other levels of government net of received transfers (indic. EDec2); (3) revenue excluding received transfers from other levels of government (Indic. RDec3). Source: IMF, Government Finance Statistical Yearbook (except for: BEL - Banque Nationale de Belgique, JAP - OECD, National Accounts). Own calculations.

At first glance, the expenditure and revenue figures indicate no unique pattern of development across countries. ${ }^{45}$ At least, with respect to total expenditure and own revenue, the degree of decentralization has risen during the period of investigation in a majority of OECD countries. As a result of the important constitutional changes, the sub-national share of expenditure and revenue increased especially in Belgium ${ }^{46}$ and Spain, and also to a lesser extent in Canada, Finland, France, Iceland, Italy, Portugal, and the USA. In contrast to this, in many countries, among others Germany, Ireland, Norway, the United Kingdom, and even Switzerland the degree of fiscal decentralization has declined. Furthermore, European Union countries are found to be on average more centralized than other OECD countries.

The picture changes to some extent when taking a closer look at the composition of

\footnotetext{
${ }^{45}$ This corresponds to earlier studies carried out by the OECD (2003) and Miñana (1998), who find clear evidence for decentralization only with respect to expenditure.

${ }^{46}$ Note that the GFS classification considers Belgian regions and communities as central government units. Therefore, previous studies using these data considerably underestimate the degree of fiscal decentralization in Belgium, particularly from 1989 on. We use instead national statistics which distinguish the different levels of sub-national government.
} 
central government expenditure and revenue. In order to focus only on government functions which could reasonably be decentralized according to the theory of fiscal federalism, social security has been removed from the central government sector (see Table 4). ${ }^{47}$ Now, the figures reveal on average a more pronounced process of decentralization both in EU- and Non-EU-countries, especially with respect to the revenue side, where 17 out of 22 countries have higher decentralization levels at the end of the 1990s. A strong process of decentralization of direct spending is notably found for Spain. These quantitative figures seem to reflect quite well the devolution of competencies and the strengthening of political autonomy of sub-central governments observed during the last decades. The partly contradicting pieces of evidence in case of excluding social security also indicate that the observed tendency to decentralize certain government activities apparently interfered with the significant rise of the welfare state in most OECD countries.

Table 4: Degree of fiscal decentralization (excl. social security), OECD countries, 1970-2001

\begin{tabular}{|c|c|c|c|c|c|c|}
\hline \multirow[t]{2}{*}{ Country } & \multicolumn{2}{|c|}{ Direct expenditure (1) } & \multicolumn{2}{|c|}{ Total expenditure (2) } & \multicolumn{2}{|c|}{ Own revenue $(3)$} \\
\hline & $1970-75$ & 1996-2001 & $1970-75$ & 1996-2001 & $1970-75$ & 1996-2001 \\
\hline AUS & 49.3 & 48.3 & 27.4 & 31.6 & 24.0 & 32.9 \\
\hline AUT & 45.8 & 47.5 & 34.9 & 33.8 & 35.1 & 33.4 \\
\hline BEL & 21.0 & 39.5 & 10.0 & 33.8 & 10.2 & 35.4 \\
\hline $\mathrm{CAN}$ & 58.5 & 63.7 & 49.6 & 56.5 & 49.3 & 55.8 \\
\hline DEN & 61.8 & 59.9 & 30.7 & 36.1 & 30.3 & 33.8 \\
\hline FIN & 42.6 & 45.2 & 30.3 & 34.7 & 30.3 & 34.7 \\
\hline FRA & 29.0 & 32.2 & 18.0 & 21.5 & 13.5 & 22.3 \\
\hline GER & 65.9 & 64.6 & 59.3 & 60.2 & 54.5 & 54.9 \\
\hline GRE & 5.0 & & 4.8 & & 4.9 & \\
\hline ICL & 21.8 & 33.7 & 21.9 & 30.1 & 19.7 & 25.6 \\
\hline IRL & 34.5 & 28.4 & 18.1 & 7.4 & 15.4 & 7.8 \\
\hline ITA & 26.2 & 36.3 & 11.7 & 17.2 & 9.1 & 16.1 \\
\hline JAP & 65.5 & 62.8 & 28.4 & 27.6 & 34.6 & 38.3 \\
\hline LUX & 26.7 & 27.6 & 14.3 & 17.5 & 11.7 & 13.3 \\
\hline NED & 53.2 & 45.9 & 11.6 & 13.7 & 5.9 & 16.2 \\
\hline NEZ & $12.5^{a}$ & 11.1 & $10.4^{a}$ & 10.0 & $11.3^{a}$ & 10.1 \\
\hline NOR & 48.1 & $46.1^{b}$ & 42.2 & $32.7^{b}$ & 40.9 & $27.2^{b}$ \\
\hline POR & 9.3 & 13.7 & 4.7 & 9.0 & 6.0 & 8.7 \\
\hline SPA & 15.6 & 63.4 & 8.7 & 30.8 & 8.2 & 26.6 \\
\hline SWE & 48.0 & 42.0 & 35.8 & 34.8 & 35.9 & 34.4 \\
\hline SWI & 74.4 & 78.2 & 63.3 & 62.2 & 62.3 & 63.0 \\
\hline UK & 36.9 & $31.6^{b}$ & 22.4 & $19.3^{b}$ & 17.9 & $18.6^{b}$ \\
\hline USA & 53.1 & 60.2 & 42.8 & 49.9 & 46.8 & 51.5 \\
\hline Median $^{c}$ : & & & & & & \\
\hline$O E C D$ & 44.2 & 45.6 & 24.9 & 31.2 & 21.9 & 30.0 \\
\hline EU15 & 35.7 & 40.8 & 18.1 & 26.2 & 14.5 & 24.4 \\
\hline
\end{tabular}

Note: Total expenditure and lending minus repayments (total revenue and grants) of sub-central government in $\%$ of consolidated general government expenditure (revenue), without social security and EU payments. Six-year-averages, ${ }^{a}$ $1978-80,{ }^{b} 1988-90,{ }^{c}$ without GRE. See Table 3 for further details.

According to the different patterns of development for expenditure and revenue, central government grants to lower levels of government seemingly tend to be substituted with own financial resources. Data on the share of revenue from - formally - own sources in

\footnotetext{
${ }^{47}$ Analogously, defense expenditure could be excluded, too. However, for the moment, we leave this to future research. See, e.g., Wasylenko (1987).
} 
total revenue of sub-central government reported by the $\mathrm{IMF}^{48}$ confirm this. For regional, as well as for local governments we find evidence for increasing reliance on revenue from own sources - irrespective of the degree of control upon their allocation. Against the general trend, the relative importance of intergovernmental grants has increased for local governments in Germany, Ireland, Norway, and, particularly, the United Kingdom. The figures also indicate that local governments in Australia, Austria, Greece, Iceland, New Zealand, Norway and Switzerland, and Länder governments in Germany rely on average only to a minor extent on grants from other levels of government.

However, as already discussed, no clear conclusions can be drawn from these figures, since budgetary data not adjusted for decision-making structures provide no clear information whether indeed fiscal powers have been transferred to lower levels of government in the course of time. Therefore, focusing on the revenue side we employ the indicators presented in section 3 in order to account for decision-making autonomy. The analysis covers the period 1965-2001 for which data from OECD Revenue Statistics are available. Based on 23 comprehensive surveys of national financial laws and constitutions for the period of investigation, revenue data and the classification of autonomy are adjusted for each sub-central government tax on an annual basis for changes occurring in the legal provisions. ${ }^{49}$

Table 5 shows that the degree of tax revenue autonomy of sub-central governments barely changes over time. A considerable increase in fiscal autonomy took place in France, especially owing to the laws granting tax-raising powers to regions, départements and municipalities at the beginning of the 1980s. With transition to democracy, sub-central governments in Greece, Portugal, and Spain have been assigned formerly national taxes and more legislative powers over already existing local taxes. In contrast to this, subcentral government reliance on autonomous taxes has significantly declined in Ireland.

However, note that the measure of fiscal autonomy is quite sensitive to changes in the assignment of taxes and tax competencies and to business cycles. Therefore, great leaps should be treated with caution. As illustrated by the cases of Belgium or Italy, consolidated data on different tiers of sub-central government might be misleading, too. The creation and endowment of regional governments with competencies and own revenues in both countries reduced the measured consolidated degree of tax autonomy, ${ }^{50}$ though, as will be seen, on the other side, this implied an increase in fiscal decentralization. These problems are therefore solved when focusing instead on the degree of fiscal decentralization which accounts for the scope of sub-central government activity.

The development of the degree of tax revenue decentralization during the period 19652001 is illustrated in Table 6 using the three different indicators elaborated in section $3 .{ }^{51}$ Though considerably differing in the level of decentralization measured, the indicators mostly confirm the trend towards an increasing role of sub-central governments in a majority of OECD countries. This is also true, even though to a lesser extent, when considering only EU member countries. However, again, there is no uniform pattern of development across countries. Pooled OLS regressions for different decentralization measures corroborate these findings, providing evidence for a positive, but mainly statis-

\footnotetext{
${ }^{48}$ See Table 8 in the appendix.

${ }^{49}$ The overview in the appendix provides only a very broad description of the most important trends in tax-raising autonomy. For the classification of taxes we have compiled more detailed annual information on the legislative competencies of sub-central governments.

${ }^{50}$ This is especially due to the assignment of shared national tax receipts.

${ }^{51}$ The corresponding analysis of total revenue decentralization is provided in Table 9 in the appendix. However, data on sub-national total revenue are missing for Greece and Japan, and are only available from 1975 on for the other countries. Though not entirely comparable, the trends are quite similar to those reported for tax revenue. The entire time series on the two most appropriate measures of tax and revenue decentralization, TDec1, and $R D e c 1$ are also reported in the Tables 11 and 12 in the appendix.
} 
Table 5: Degree of tax revenue autonomy of sub-central government, 1965-2001

\begin{tabular}{|c|c|c|c|c|c|}
\hline \multirow[t]{2}{*}{ Country } & \multirow[t]{2}{*}{ Lev. gov. } & \multicolumn{2}{|c|}{ TAut1 (1) } & \multicolumn{2}{|c|}{ TAut2 (2) } \\
\hline & & $1965-67$ & 1999-2001 & $1965-67$ & $1999-2001$ \\
\hline \multirow[t]{2}{*}{ AUS } & Regional & 100.0 & 100.0 & 100.0 & 100.0 \\
\hline & Local & 0.0 & 0.0 & 0.0 & 0.0 \\
\hline \multirow[t]{2}{*}{$\mathrm{AUT}$} & Regional & $1.9^{a}$ & 2.5 & 100.0 & 100.0 \\
\hline & Local & $16.9^{a}$ & 17.7 & 100.0 & 100.0 \\
\hline BEL & Reg./Loc. ${ }^{c}$ & 92.6 & 55.0 & 92.6 & 99.3 \\
\hline \multirow[t]{2}{*}{$\mathrm{CAN}$} & Regional & 100.0 & 98.9 & 100.0 & 100.0 \\
\hline & Local & 100.0 & 95.0 & 100.0 & 95.0 \\
\hline DEN & Local & $96.7^{a}$ & 94.5 & $96.7^{a}$ & 94.5 \\
\hline FIN & Reg./Loc. ${ }^{c}$ & 88.8 & 81.5 & 88.8 & 81.5 \\
\hline FRA & Reg./Loc. ${ }^{c}$ & $12.1^{b}$ & 99.0 & $12.1^{b}$ & 99.0 \\
\hline \multirow[t]{2}{*}{ GER } & Regional & 0.0 & 0.0 & 100.0 & 100.0 \\
\hline & Local & $55.6^{a}$ & 56.5 & 100.0 & 100.0 \\
\hline GRE & Local & $6.4^{a}$ & 13.8 & $6.4^{a}$ & 13.8 \\
\hline ICL & Local & 100.0 & 100.0 & 100.0 & 100.0 \\
\hline IRL & Local & 100.0 & 54.1 & 100.0 & 54.1 \\
\hline ITA & Reg./Loc. ${ }^{c}$ & 97.1 & 89.8 & 97.1 & 89.8 \\
\hline JAP & Local & 88.1 & 91.0 & 88.1 & 91.0 \\
\hline LUX & Local & 100.0 & 99.6 & 100.0 & 99.6 \\
\hline \multirow[t]{2}{*}{ NED } & Regional & & 100.0 & & 100.0 \\
\hline & Local & 100.0 & 100.0 & 100.0 & 100.0 \\
\hline NEZ & Reg./Loc. ${ }^{c}$ & 100.0 & 98.8 & 100.0 & 98.8 \\
\hline NOR & Local & 100.0 & 98.0 & 100.0 & 98.0 \\
\hline POR & Reg./Loc. ${ }^{c}$ & 0.0 & 36.8 & 0.0 & 36.8 \\
\hline SPA & Reg./Loc. ${ }^{c}$ & $65.4^{a}$ & 86.2 & $65.4^{a}$ & 92.0 \\
\hline \multirow[t]{2}{*}{ SWE } & Regional & 100.0 & 100.0 & 100.0 & 100.0 \\
\hline & Local & 100.0 & 100.0 & 100.0 & 100.0 \\
\hline \multirow[t]{2}{*}{ SWI } & Regional & 93.5 & 88.9 & 100.0 & 100.0 \\
\hline & Local & 100.0 & 100.0 & 100.0 & 100.0 \\
\hline UK & Local & 100.0 & 100.0 & 100.0 & 100.0 \\
\hline \multirow[t]{2}{*}{ USA } & Regional & 100.0 & 100.0 & 100.0 & 100.0 \\
\hline & Local & 100.0 & 100.0 & 100.0 & 100.0 \\
\hline
\end{tabular}

Note: As per cent of total tax revenue of sub-central government. In case of various regional or local tiers of government, these are consolidated at each corresponding level of government. Three-year-averages. ${ }^{a} 1973-75 ;{ }^{b} 1970 ;{ }^{c}$ due to problems of identification, local and regional level of government are consolidated. Degree of tax autonomy as defined in section 3: (1) autonomous own taxes, (2) autonomous own and shared taxes. Source for the data: OECD, Revenue Statistics. Source for tax classification: OECD (1997, 1999, 2002b), Committee of the Regions (1999, 2000, 2001), Council of Europe, European Commission (2002), Döhler (2002), Engel and van Ginderachter (1992), Fossatti and Panella (1999), Norton (1994), Ter-Minassian (1997), Rahmann et al. (1994), and national fiscal constitutions and laws. Own calculations.

tically insignificant linear trend. ${ }^{52}$ Focusing on the indicator which best represents tax autonomy (TDec1), we notice a significant increase of fiscal decentralization in Belgium and Spain. Apart from these two cases, decentralization trends are reported in France, Iceland, Italy, Japan, Portugal, and Sweden, too. On the other hand, sub-central government has been pushed back in Ireland, New Zealand, Norway, and the United Kingdom. This quantitative evidence seems to reflect very well the institutional changes taking place in these countries.

With minor exceptions, this pattern of development is generally confirmed when adding the revenue from shared taxes upon the allocation of which sub-central governments have significant control (TDec2), or when considering total tax receipts irrespective of

\footnotetext{
${ }^{52}$ The regression results for different indicators of decentralization are provided in Table 10 in the appendix.
} 
decision-making structures (TDec3). However, the magnitude of the changes varies considerably depending on the indicator employed.

Table 6: Degree of tax revenue decentralization, OECD countries, 1965-2001

\begin{tabular}{|c|c|c|c|c|c|c|}
\hline & \multicolumn{2}{|c|}{ TDec1 (1) } & \multicolumn{2}{|c|}{ TDec2 (2) } & \multicolumn{2}{|c|}{ TDec3 (3) } \\
\hline & 1965-67 & 1999-2001 & 1965-67 & 1999-2001 & $1965-67$ & 1999-2001 \\
\hline AUS & $19.6^{a}$ & 19.1 & $19.6^{a}$ & 19.1 & $19.6^{a}$ & 19.1 \\
\hline AUT & $3.2^{a}$ & 3.2 & $29.5^{a}$ & 28.2 & $29.5^{a}$ & 28.2 \\
\hline BEL & 6.6 & 24.6 & 6.6 & 44.4 & 7.2 & 44.7 \\
\hline $\mathrm{CAN}$ & 52.1 & 51.8 & 52.1 & 51.8 & 52.1 & 51.8 \\
\hline DEN & $27.4^{a}$ & 32.2 & $27.4^{a}$ & 32.2 & $28.4^{a}$ & 34.1 \\
\hline FIN & 23.4 & 24.2 & 23.4 & 24.2 & 26.3 & 29.7 \\
\hline FRA & $1.1^{b}$ & 18.4 & $1.1^{b}$ & 18.4 & $9.4^{b}$ & 18.6 \\
\hline GER & $7.6^{a}$ & 7.2 & $48.3^{a}$ & 49.3 & $48.3^{a}$ & 49.3 \\
\hline GRE & $0.3^{a}$ & 0.3 & $0.3^{a}$ & 0.3 & $4.9^{a}$ & 1.9 \\
\hline ICL & $19.2^{a}$ & 25.3 & $19.2^{a}$ & 25.3 & $19.2^{a}$ & 25.3 \\
\hline IRL & 12.8 & 2.2 & 12.8 & 2.2 & 12.8 & 4.0 \\
\hline ITA & 6.3 & 11.2 & 6.3 & 11.2 & 6.5 & 14.8 \\
\hline JAP & 28.6 & 37.5 & 28.6 & 37.5 & 32.5 & 41.3 \\
\hline LUX & 10.0 & 7.9 & 10.0 & 7.9 & 10.0 & 8.0 \\
\hline NED & $2.1^{a}$ & 5.1 & $2.1^{a}$ & 5.1 & $2.1^{a}$ & 5.1 \\
\hline NEZ & 8.8 & 5.9 & 8.8 & 5.9 & 8.8 & 6.0 \\
\hline NOR & $31.0^{a}$ & 21.4 & $31.0^{a}$ & 21.4 & $31.0^{a}$ & 21.8 \\
\hline POR & 0.0 & 3.3 & 0.0 & 3.3 & 0.3 & 8.9 \\
\hline SPA & $5.1^{a}$ & 22.3 & $5.1^{a}$ & 23.8 & $7.8^{a}$ & 25.9 \\
\hline SWE & 32.0 & 42.8 & 32.0 & 42.8 & 32.0 & 42.8 \\
\hline SWI & 54.0 & 53.0 & 56.0 & 56.9 & 56.0 & 56.9 \\
\hline UK & 13.6 & 5.0 & 13.6 & 5.0 & 13.6 & 5.0 \\
\hline USA & 34.5 & 35.6 & 34.5 & 35.6 & 34.5 & 35.6 \\
\hline $\begin{array}{l}\text { Median: } \\
O E C D\end{array}$ & 12.8 & 19.1 & 19.2 & 23.8 & 19.2 & 25.4 \\
\hline EU15 & 6.6 & 7.9 & 10.0 & 18.4 & 10.0 & 18.6 \\
\hline Mean: & & & & & & \\
\hline$O E C D$ & 17.4 & 20.0 & 20.4 & 24.0 & 21.4 & 25.2 \\
\hline EU15 & 10.1 & 14.0 & 14.6 & 19.9 & 15.9 & 21.4 \\
\hline Std.dev.: & & & & & & \\
\hline$O E C D$ & 15.39 & 15.74 & 16.43 & 17.03 & 15.86 & 16.68 \\
\hline EU15 & 9.74 & 12.32 & 13.92 & 16.08 & 13.26 & 15.66 \\
\hline
\end{tabular}

Note: Tax revenue of sub-central governments in \% of consolidated general government tax revenue, without social security and EU payments. Three-year-averages. ${ }^{a} 1973-75,{ }^{b}$ 1970. Degree of tax revenue decentralization as defined in section 3 : (1) autonomous own taxes, (2) autonomous own and shared taxes, (3) total tax revenue of sub-central levels of government. Source: see Table 5.

With regard to Germany, these figures confirm the results of the related analysis of Blankart (1999) who identifies a process of "hidden centralization" in Germany, the degree of tax revenue decentralization dropping from $40 \%$ in 1950 to $7 \%$ in $1995 .{ }^{53}$ At the same time the trend in Switzerland went in the opposite direction, the degree of tax decentralization increasing to $53 \%$. The figures for 1995 correspond exactly to the own calculations reported in the third column of Table 6.

\footnotetext{
${ }^{53}$ Note that this considerable centralization occurred with the constitutional reforms of 1955 and 1969 which transferred certain taxes from the Länder to the federal government and extended the scope of concurrent legislation. Since Revenue Statistics data for Germany are only available from 1973 on, this process is therefore not reflected by the figures in the present analysis.
} 
Even if this measure of fiscal decentralization accounts for decision-making competencies, it still does not provide a remedy to all limitations of aggregate fiscal measures described in section 2. Tax bases of central and sub-central governments typically have different elasticities. Therefore, business cycles cause automatic fluctuations of the tax revenue indicators, even though the assignment of competencies remains unchanged. For example, the sub-national share of total tax revenue might fall when local governments rely heavily on taxing relatively mobile bases. ${ }^{54}$ Yet, this could not be interpreted as increasing fiscal decentralization. On the other side, fiscal decentralization might not be depicted by the aggregate indicator, when, for instance, the transfer of tax-raising powers to sub-central levels of government interferes with increasing revenue of central government. Also, the shift from the positive to the regulatory state observed since the late $1970 \mathrm{~s}^{55}$ which implies central government increasingly relying on rules, norms, and minimum quality standards, is not captured by fiscal data. Therefore, local fiscal autonomy might be restrained without being adequately quantified.

However, in comparison to conventional measures, indicators accounting for decisionmaking structures have the definite advantage of providing in most cases a better distinction between real fiscal decentralization and sheer revenue effects. Even if the assignment of tax receipts to levels of government remains unchanged, the extension of legislative competencies upon these taxes is reflected by an increase in these indicators of decentralization. Therefore, besides providing a better approximation for the actual level of fiscal decentralization, changes in the vertical government structure are better reflected, too.

\section{$6 \quad$ Summary and conclusions}

Motivated by increasing interest in public finance and practice on the comparison of vertical government structures, this paper has given an analysis of the problems encountered in measuring the degree of fiscal decentralization and has provided an overview of recent international trends.

Conventional measures of the degree of fiscal decentralization widely used in the literature relate expenditure and revenue of sub-central governments to expenditure and revenue of consolidated general government, as derived from financial statistics. However, the discussion in this paper shows that these measures based on budgetary shares do not appropriately capture decision-making structures and the extent of autonomy of subcentral government upon the allocation of their expenditure and revenue. Due to these measurement errors, the actual degree of fiscal decentralization tends to be overestimated and especially the results of empirical studies using such fiscal indicators as explanatory variables may be seriously distorted.

In view of the predominant importance of the provision with own financial resources for sub-national autonomy and the scope of public spending, the present analysis focused on the revenue side of fiscal decentralization. Drawing on a recent analytical framework provided by the OECD, different indicators of tax autonomy and revenue decentralization are constructed which take tax-raising powers of sub-central governments into account. The new contribution consists both in deriving alternative measures of decentralization, and in providing more recent figures and a comprehensive analysis of the long-term development of vertical government structures in OECD countries. Based on the OECD method of classification of local taxes according to the degree of discretion of sub-central governments, the degree of fiscal decentralization is measured by the share of sub-central

\footnotetext{
${ }^{54}$ See OECD (2003).

${ }^{55}$ See Majone (1997).
} 
government revenue from taxes or other resources which are significantly controlled by them in total revenue of consolidated general government. Using annual data for over 30 years reported by the Revenue Statistics and taking account of changes in the assignment of tax-raising powers to sub-central governments on an annual basis, new time series are provided for 23 OECD countries, including also countries not considered in the OECD study.

The comparison of figures based on different measurement concepts indicates that common fiscal indicators considerably overestimate the degree of fiscal decentralization or fiscal autonomy in most countries. Especially federal countries like Germany or Austria are shown to be more centralized than unitary countries like Denmark or France. Only when sub-central governments have considerable control over their financial resources, common indicators are reasonable proxies of public sector decentralization.

With respect to the development over time, both conventional and improved indicators provide strong evidence for increasing fiscal decentralization in a majority of OECD countries during the last three decades. Particularly sub-central governments in Spain, Belgium, France and Italy are increasingly relying on own autonomous revenues. However, no uniform pattern could be determined, several countries also exhibiting tendencies to centralize government activity. Also, with few important exceptions, vertical government structures seem to change only gradually in the course of time, displaying significant inertia. Therefore, even longer periods of investigation might be necessary to detect significant long-term trends.

To conclude, conventional expenditure and revenue shares are shown to often misrepresent the actual level of fiscal decentralization, therefore being unsuited for cross-country comparisons. On the other side, even though differing considerably in the magnitude, both conventional and adjusted fiscal indicators seem to perform well in describing longterm trends in the public sector. Despite several shortcomings related to aggregation and the use of budgetary data, when adjusted for decision-making structures, expenditure and revenue shares still have the definite advantage of being operational. The new data set provided in this paper therefore might contribute to improving empirical studies on fiscal decentralization.

Also, as suggested in this paper, the analysis of fiscal decentralization could analogously be extended to classify sub-central expenditure or borrowing according to the degree of autonomy. Generally speaking, it seems reasonable to use a set of different indicators instead of a single measure in order to represent the different aspects of decentralization. However, the measure of decentralization to be selected in empirical studies ultimately depends on the specific purpose of the investigation. 


\section{Appendix}

Table 7: Levels of government, OECD countries

\begin{tabular}{|c|c|c|c|}
\hline Country & Regional level of governm. & Local level of governm. & Special status territor. \\
\hline Australia & states, territories & municipalities & \\
\hline Austria & Länder & municipalities & \\
\hline Belgium & regions & provinces & \\
\hline & communities & municipalities & \\
\hline Canada & provinces, territories & municipalities & \\
\hline Denmark & & $\begin{array}{l}\text { counties } \\
\text { municipalities }\end{array}$ & Faroe Isl., Greenland \\
\hline Finland & & municipalities & auton. province Aland \\
\hline France & $\begin{array}{l}\text { regions } \\
\text { départements }\end{array}$ & municipalities & $\begin{array}{l}\text { TOM } \\
\text { Corsica }\end{array}$ \\
\hline Germany & Länder & $\begin{array}{l}\text { districts } \\
\text { municipalities }\end{array}$ & \\
\hline Greece & & $\begin{array}{l}\text { prefectures } \\
\text { municipalities }\end{array}$ & \\
\hline Iceland & & municipalities & \\
\hline Ireland & & $\begin{array}{l}\text { counties, cnty. boroughs } \\
\text { boroughs, urban districts }\end{array}$ & \\
\hline Italy & $\begin{array}{l}\text { regions } \\
\text { provinces }\end{array}$ & municipalities & special auton. regions \\
\hline Japan & & $\begin{array}{l}\text { prefectures } \\
\text { municipalities }\end{array}$ & \\
\hline Luxembourg & & municipalities & \\
\hline Netherlands & provinces & $\begin{array}{l}\text { polder boards } \\
\text { municipalities }\end{array}$ & \\
\hline $\begin{array}{l}\text { New Zealand } \\
\text { Norway }\end{array}$ & regional councils & $\begin{array}{l}\text { territorial authorities } \\
\text { counties } \\
\text { municipalities }\end{array}$ & \\
\hline Portugal & & $\begin{array}{l}\text { municipalities } \\
\text { parishes }\end{array}$ & Azores, Madeira \\
\hline Spain & autonomous communities & $\begin{array}{l}\text { provinces } \\
\text { municipalities }\end{array}$ & historical regions \\
\hline Sweden & county councils & $\begin{array}{l}\text { municipalities } \\
\text { parishes }\end{array}$ & \\
\hline Switzerland & cantons & $\begin{array}{l}\text { municipalities } \\
\text { parishes }\end{array}$ & \\
\hline United Kingdom & & $\begin{array}{l}\text { counties, districts } \\
\text { unitary authorities }\end{array}$ & Scotland, Wales, N.Irl. \\
\hline United States & states & $\begin{array}{l}\text { counties, districts } \\
\text { municipalities }\end{array}$ & \\
\hline
\end{tabular}

Note: Units of government with own or assigned tax revenues. Own compilation. 
Fiscal decentralization in OECD countries (competencies, polit. autonomy), 1970-2004

\begin{tabular}{|c|c|}
\hline AUS & 1970s increasing overlap of central/state gov. competencies \\
\hline AUT & $\begin{array}{l}1974,1983 / 84,1988 \text { role of federal chamber and competencies of Länder strengthened } \\
1992 \text { agreement on const. reform (not implemented): devolution, abolition of direct state admin. }\end{array}$ \\
\hline BEL & $\begin{array}{l}1970 \text { creation of communities/regions, devolution of competencies to communities, co-decision rules } \\
1980,1988 \text { devolution of legislative competencies to elected regional and community gov. } \\
1994 \text { constitutional reform: federal state }\end{array}$ \\
\hline CAN & $\begin{array}{l}1982 \text { constitutional reform: strengthening of the provinces } \\
1987 \text { const. reform (failed): strengthening of the provinces and of the autonomy of Québec } \\
\text { in the course of time federal gov. competencies delegated to provinces }\end{array}$ \\
\hline DEN & $\begin{array}{l}1970 \text { competencies of local gov. extended to all local affairs; reduction of state supervision } \\
1976 \text { responsibility for social security transferred to local gov. } \\
1980 \text { s, } 1990 \text { further devolution of competencies }\end{array}$ \\
\hline FIN & $\begin{array}{l}1976 \text { strengthening of local self-government } \\
1994-97 \text { creation of self-governed regional councils responsible for regional development }\end{array}$ \\
\hline FRA & $\begin{array}{l}\text { 1982-83 devolution competencies to subnat. gov., elected regional gov., reduced state supervision } \\
2002 \text { devolution competencies to subnat. gov. } \\
2003-04 \text { constitutional reform: devolution competencies to subnat. gov. }\end{array}$ \\
\hline GER & $\begin{array}{l}\text { in the course of time increase of Länder participation in federal legislation } \\
1992 \text { extension of participation of Länder gov. in EU policy }\end{array}$ \\
\hline GRE & $\begin{array}{l}1975 \text { democratic constitution: creation of first level of local self-government } \\
1986-87 \text { administrat. decentralization, creation development regions } \\
1994 \text { creation of second level of local self-gov. (prefectures), extended competencies loc./reg. gov. } \\
1997 \text { creation of development regions with own budgets } \\
1997-2001 \text { devolution competencies to local gov. } \\
2001 \text { const. reform: strengthening of local self-government, reduced state supervision }\end{array}$ \\
\hline ICL & \\
\hline IRL & $\begin{array}{l}1977,1983,1987 \text { certain minor functions devolved to local gov. } \\
1986,1994 \text { creation of regions as decentralized units of central gov. } \\
1999 \text { constitutional reform: recognition of elected local government bodies }\end{array}$ \\
\hline ITA & $\begin{array}{l}1970 \text { creation of regions with ordinary statute } \\
1972,1977 \text { devolution of administrative competencies to ordinary regions, local gov. } \\
1990-92 \text { extension local/regional competen., local self-govern., subsidiarity, reduced state supervision } \\
1993 \text { direct election of mayors and province presidents } \\
1997-98 \text { devolution of competencies to regions/local gov. ("administrative federalism") } \\
1999 \text { direct election of regional presidents } \\
\text { 2001-03 const. reform: federalization, devolution of legislative competencies to regions, autonomy, } \\
\text { end of state supervision }\end{array}$ \\
\hline JAP & 1995 law to promote decentralization \\
\hline LUX & $\begin{array}{l}1979 \text { constitutional reform: local self-government } \\
1988 \text { extension of local self-government, reduction of state supervision }\end{array}$ \\
\hline NED & 1983, 1994 strengthening of provincial and local gov. vs. central gov. \\
\hline NEZ & 1974 creation of self-governed regional councils \\
\hline NOR & 1977 administrative independence of counties, strengthening of municipalities \\
\hline POR & $\begin{array}{l}1976 \text { democratic const.: local self-govern., devolution competencies, autonomy Madeira/Azores } \\
1979 \text { creation of development regions } \\
1999 \text { devolution competencies local gov., Madeira and Azores }\end{array}$ \\
\hline SPA & $\begin{array}{l}1978 \text { democratic constitution: regional and local autonomy } \\
1981-83 \text { creation of auton. regions, abolition state supervision, devolution competencies to regions } \\
1992-93 \text { extension of competencies of regions }\end{array}$ \\
\hline SWE & $\begin{array}{l}1970 \text { reduction of provincial gov. competencies } \\
1997,1999 \text { creation of self-governed pilot regions, responsible for regional development }\end{array}$ \\
\hline SWI & reform of distribution of government functions currently planned \\
\hline UK & $\begin{array}{l}1972 \text { N. Ireland: abolition of self-government and dissolution of regional parliament } \\
1973 \text { extension of competencies of local gov. } \\
1980-85 \text { reduction of competencies of local gov. } \\
1994 \text { creation of administrative government offices for the regions (GOR) } \\
1998 \text { N. Ireland: restoration of self-government, election of regional parliament } \\
1999 \text { Scotl., Wales: elected parliaments, legisl. and admin. competencies, state supervision reduced } \\
\text { England: creation of regional development agencies (RDA), elected bodies planned } \\
\text { 2000 London: direct election of council and mayor }\end{array}$ \\
\hline USA & extension of federal gov. legislation in areas of state and local gov. (e.g., social affairs) \\
\hline
\end{tabular}


Fiscal decentralization in OECD countries (financial autonomy), 1970-2004

\begin{tabular}{|c|c|}
\hline AUS & $\begin{array}{l}1971 \text { cession of payroll tax to states } \\
2000 \text { cession of general sales tax receipts to states }\end{array}$ \\
\hline \multicolumn{2}{|r|}{ 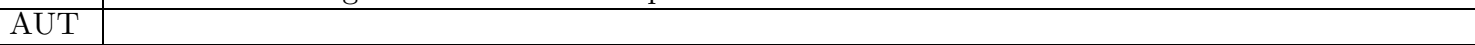 } \\
\hline BEL & $\begin{array}{l}1980 \text { assignment of own revenues with limited legislative power to communities/regions } \\
\text { 1989, 1994, 2001-02 extension of own sources and tax-rising powers of communities/regions, } \\
\text { co-decision on financing system }\end{array}$ \\
\hline \multicolumn{2}{|l|}{$\mathrm{CAN}$} \\
\hline DEN & 1996 complete cession of county land tax yield to counties \\
\hline \multicolumn{2}{|l|}{ FIN } \\
\hline FRA & $\begin{array}{l}1980 \text { tax-raising autonomy for direct local taxes } \\
1983 \text { cession of national taxes and legislat. competencies to départements/regions } \\
1999-2001 \text { abolition of certain local/regional tax bases } \\
2003 \text { constitutional reform: financial autonomy of subnat. gov. }\end{array}$ \\
\hline GER & $\begin{array}{l}1969 \text { const. reform: extension of concurrent competencies and cession of Länder taxes, } \\
\text { to central gov., revenue-sharing of personal and corporate income tax and VAT } \\
1996 \text { abolition of the Länder wealth tax } \\
1997 \text { communal enterprise capital tax replaced with share in VAT }\end{array}$ \\
\hline GRE & $\begin{array}{l}1990 \text { local gov. shares in national taxes } \\
2001 \text { constitutional reform: financial autonomy of subnat. gov. }\end{array}$ \\
\hline \multicolumn{2}{|r|}{ - } \\
\hline IRL & 1997 local gov. share of motor tax yield \\
\hline ITA & $\begin{array}{l}\text { 1973-74 abolition of local taxes, centralization of tax administration } \\
1989-93 \text { substitution of grants with new local/regional taxes, legislative powers } \\
1998 \text { introduction of further regional/local taxes and surcharges to national taxes } \\
2000 \text { substitution of grants with regional share in national taxes } \\
2001 \text { constitutional reform: financial autonomy of local/regional gov. }\end{array}$ \\
\hline \multicolumn{2}{|r|}{ 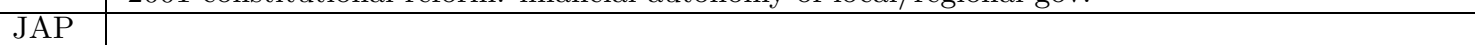 } \\
\hline LUX & 1979 financial autonomy of local gov. \\
\hline NED & in the course of time abolition of certain local taxes \\
\hline \multicolumn{2}{|l|}{ NEZ } \\
\hline NOR & 1979 tax-raising power of counties, county income tax \\
\hline POR & $\begin{array}{l}1979 \text { own local taxes; special taxing powers Madeira and Azores } \\
1989-90 \text { new local taxes, legislative competencies of local gov. } \\
1997 \text { constitutional reform: local tax-raising powers } \\
1999 \text { local gov. share in national taxes }\end{array}$ \\
\hline SPA & $\begin{array}{l}\text { 1981-82 cession of national and own taxes to regions, regional share in national taxes } \\
1987 \text { co-decision of regions on financing system, extended shares in national taxes } \\
1988-90 \text { new local and provincial taxes } \\
1993 \text { regional share in national income tax, extended legislat. competencies for shared taxes } \\
1997 \text { extended regional share in national income tax and additional regional surcharge, extended } \\
\text { legislat. competencies for regional shared taxes } \\
2002 \text { extended reg. share in national income tax and surcharge, cession of taxes to regions }\end{array}$ \\
\hline SWE & $\begin{array}{l}1986 \text { reduction of the local income tax base } \\
1991-2000 \text { temporary limits on local tax rates set by central gov. }\end{array}$ \\
\hline SWI & 1993 harmonization of cantonal tax legislations \\
\hline UK & $\begin{array}{l}1980-84 \text { reduction of legislative competencies for local taxes } \\
1990 \text { transfer of certain local taxes to central gov. } \\
1999 \text { tax legislative competencies for Scottish Parliament }\end{array}$ \\
\hline USA & \\
\hline
\end{tabular}


Table 8: Own revenue of sub-central government, OECD countries, 1970-2001

\begin{tabular}{l|l|cc}
\hline \hline Country & Lev. gov. & $1970-75$ & $1996-2001$ \\
\hline AUS & Regional & 46.0 & 61.0 \\
& Local & 80.6 & 84.3 \\
AUT & Regional & 56.3 & 51.2 \\
& Local & 85.7 & 82.6 \\
BEL & Regional & & 91.4 \\
& Local & 49.7 & 54.4 \\
CAN & Regional & 76.1 & 85.1 \\
& Local & 51.2 & 61.8 \\
DEN & Local & 50.7 & 59.5 \\
FIN & Local & 70.0 & 76.1 \\
FRA & Local & 54.5 & 66.1 \\
GER & Regional & 81.5 & 81.9 \\
& Local & 69.5 & 66.7 \\
GRE & Local & 85.6 & \\
ICL & Local & $90.6^{a}$ & 89.3 \\
IRL & Local & 42.9 & 22.3 \\
ITA & Local & 26.9 & 43.2 \\
JAP & Local & 49.4 & 51.6 \\
LUX & Local & 53.0 & 63.5 \\
NED & Local & 12.0 & 33.5 \\
NEZ & Local & $81.7^{b}$ & 91.1 \\
NOR & Local & 82.8 & 61.4 \\
POR & Local & 50.0 & 63.0 \\
SPA & Regional & $19.3^{c}$ & 26.5 \\
& Local & 51.9 & 65.9 \\
SWE & Local & 70.6 & 82.6 \\
SWI & Regional & 71.1 & 69.1 \\
& Local & 82.2 & 84.1 \\
UK & Local & 51.9 & 28.6 \\
USA & Regional & 74.2 & 77.9 \\
& Local & 60.4 & 62.1 \\
\hline & & &
\end{tabular}

Note: Revenue exclusive of intergovernmental grants received from other levels of government, in $\%$ of total revenue and grants. Six-year-averages; ${ }^{a} 1983-84,{ }^{b} 1978-80,{ }^{c} 1980$. Source: IMF, Government Finance Statistical Yearbook (except for: BEL - Banque Nationale de Belgique, JAP - OECD, National Accounts). Own calculations. 
Table 9: Degree of revenue decentralization, OECD countries, 1975-2001

\begin{tabular}{|c|c|c|c|c|c|c|}
\hline & \multicolumn{2}{|c|}{ RDec1 (1) } & \multicolumn{2}{|c|}{ RDec2 (2) } & \multicolumn{2}{|c|}{ RDec3 (3) } \\
\hline & $1975-77^{a}$ & $1999-2001^{b}$ & $1975-77^{a}$ & $1999-2001^{b}$ & $1975-77^{a}$ & $1999-2001^{b}$ \\
\hline AUS & 23.9 & 30.8 & 23.9 & 30.8 & 23.9 & 30.8 \\
\hline AUT & 13.3 & 13.2 & 35.5 & 33.8 & 35.5 & 33.8 \\
\hline BEL & 7.2 & 25.0 & 7.2 & 43.7 & 7.3 & 44.0 \\
\hline $\mathrm{CAN}$ & 54.7 & 56.6 & 54.7 & 56.6 & 54.7 & 56.6 \\
\hline DEN & 31.8 & 32.7 & 31.8 & 32.7 & 32.6 & 34.3 \\
\hline FIN & 33.1 & 30.0 & 33.1 & 30.0 & 35.2 & 34.3 \\
\hline FRA & 6.2 & 22.8 & 6.2 & 22.8 & 15.3 & 23.0 \\
\hline GER & 21.7 & 20.8 & 54.6 & 50.1 & 54.6 & 50.1 \\
\hline GRE & & & & & & \\
\hline ICL & 18.9 & 26.2 & 18.9 & 26.2 & 18.9 & 26.2 \\
\hline IRL & 14.3 & 9.1 & 14.3 & 9.1 & 14.3 & 10.8 \\
\hline ITA & 6.2 & 10.0 & 6.2 & 10.0 & 8.9 & 16.5 \\
\hline JAP & & & & & & \\
\hline LUX & 10.5 & 12.9 & 10.5 & 12.9 & 10.5 & 12.9 \\
\hline NED & 7.6 & 13.7 & 7.6 & 13.7 & 7.6 & 13.7 \\
\hline NEZ & 12.0 & 9.8 & 12.0 & 9.8 & 12.3 & 9.9 \\
\hline NOR & 27.2 & 25.1 & 27.2 & 25.1 & 27.2 & 25.5 \\
\hline POR & 4.1 & 7.4 & 4.1 & 7.4 & 10.3 & 11.7 \\
\hline SPA & 11.8 & 24.7 & 11.8 & 25.8 & 14.7 & 27.5 \\
\hline SWE & 42.9 & 38.5 & 42.9 & 38.5 & 42.9 & 38.5 \\
\hline SWI & 63.8 & 60.1 & 66.5 & 63.0 & 66.5 & 63.0 \\
\hline UK & 18.8 & 9.1 & 18.8 & 9.1 & 18.8 & 9.1 \\
\hline USA & 41.1 & 45.8 & 41.1 & 45.8 & 41.1 & 45.8 \\
\hline Median: & & & & & & \\
\hline$O E C D$ & 18.8 & 24.7 & 18.9 & 26.2 & 18.9 & 27.5 \\
\hline EU15 & 12.5 & 17.3 & 13.0 & 24.3 & 15.0 & 25.2 \\
\hline Mean: & & & & & & \\
\hline$O E C D$ & 22.4 & 25.0 & 25.2 & 28.4 & 26.3 & 29.4 \\
\hline EU15 & 16.4 & 19.3 & 20.3 & 24.3 & 22.0 & 25.7 \\
\hline Std.dev.: & & & & & & \\
\hline$O E C D$ & 16.32 & 14.92 & 17.98 & 16.24 & $1 \% .11$ & 15.65 \\
\hline EU15 & 11.47 & 9.58 & 15.62 & 13.73 & 14.64 & 13.10 \\
\hline
\end{tabular}

Note: Own revenue of sub-central government, excluding received transfers from other levels of government, in $\%$ of consolidated general government own revenue, without social security and EU payments. Three-year-averages, ${ }^{a}$ earliest available years, ${ }^{b}$ latest available years. Degree of tax revenue decentralization as derived in section 3: (1) autonomous tax revenue, (2) limited autonomous tax revenue, (3) total tax revenue of sub-central levels of government. Source: see Table 5. 
Table 10: Decentralization trends, OLS regressions, 1965-2001

\begin{tabular}{l|c|c|c|c}
\hline \hline & \multicolumn{4}{|l}{ Dep. Variable: } \\
& TDec1 & TDec3 & RDec1 & RDec3 \\
\hline Trend & 0.009 & 0.113 & 0.193 & 0.186 \\
(OECD) & $(0.061)$ & $(0.062)$ & $(0.111)$ & $(0.118)$ \\
\hline No. obs. & 761 & 761 & 466 & 466 \\
\hline Trend & 0.073 & 0.241 & 0.061 & 0.102 \\
(EU15) & $(0.053)$ & $(0.063)$ & $(0.089)$ & $(0.122)$ \\
\hline No. obs. & 492 & 492 & 303 & 303 \\
\hline
\end{tabular}

Note: Pooled OLS regression on a linear trend. Robust, heteroskedasticity consistent standard errors (in brackets). 
Table 11: Degree of tax revenue decentralization, OECD countries, annual figures, 1965-2001

\begin{tabular}{|c|c|c|c|c|c|c|c|c|c|c|c|c|c|c|c|c|c|c|c|}
\hline & 1965 & 1966 & 1967 & 1968 & 1969 & 1970 & 1971 & 1972 & 1973 & 1974 & 1975 & 1976 & 1977 & 1978 & 1979 & 1980 & 1981 & 1982 & 1983 \\
\hline AUS & & & & & & & & & 19.68 & 19.28 & 19.94 & 19.77 & 19.72 & 19.58 & 18.85 & 18.19 & 18.30 & 19.24 & 19.49 \\
\hline AUT & & & & & & & & & 2.90 & 3.09 & 3.62 & 3.61 & 3.47 & 3.36 & 3.35 & 3.39 & 3.50 & 3.53 & 3.67 \\
\hline BEL & 6.59 & 6.70 & 6.64 & 7.30 & 6.18 & 6.69 & 6.40 & 7.07 & 6.33 & 6.72 & 6.30 & 6.09 & 5.98 & 6.11 & 6.19 & 5.31 & 5.65 & 6.48 & 6.33 \\
\hline CAN & 52.14 & 52.38 & 51.86 & 51.21 & 49.15 & 49.79 & 49.56 & 49.27 & 47.26 & 46.31 & 47.08 & 49.37 & 52.91 & 54.28 & 52.77 & 51.64 & 49.43 & 51.24 & 53.03 \\
\hline DEN & & & & & & & & & 27.35 & 25.96 & 29.02 & 29.17 & 28.65 & 27.89 & 28.62 & 28.68 & 28.92 & 29.63 & 30.22 \\
\hline FIN & 23.14 & 23.47 & 23.54 & 22.67 & 24.37 & 24.19 & 24.82 & 23.88 & 23.85 & 24.62 & 26.90 & 25.90 & 27.13 & 26.41 & 27.30 & 25.65 & 26.21 & 26.60 & 26.50 \\
\hline FRA & & & & & & 1.13 & & & 1.93 & 1.63 & 2.18 & 2.06 & 2.25 & 2.28 & 2.39 & 11.85 & 11.96 & 11.97 & 12.83 \\
\hline GER & & & & & & & & & 7.49 & 7.58 & 7.76 & 8.01 & 7.91 & 7.62 & 7.34 & 7.65 & 7.15 & 7.09 & 7.38 \\
\hline GRE & & & & & & & & & & & 0.31 & 0.25 & 0.57 & 0.54 & 0.37 & 0.40 & 0.47 & 0.43 & 0.28 \\
\hline ICL & & & & & & & & & & & 19.19 & & & & & 17.54 & 17.06 & 16.94 & 17.81 \\
\hline IRL & 13.78 & 12.98 & 11.68 & 11.75 & 11.14 & 10.99 & 11.63 & 11.71 & 9.68 & 9.64 & 8.66 & 8.33 & 7.33 & 4.90 & 4.66 & 4.08 & 3.27 & 2.54 & 2.46 \\
\hline ITA & 6.43 & 6.38 & 6.05 & 5.96 & 5.78 & 5.20 & 5.34 & 5.76 & 4.87 & 1.99 & 1.07 & 0.84 & 0.29 & 0.23 & 0.15 & 0.47 & 0.53 & 0.50 & 0.40 \\
\hline JAP & 28.33 & 28.71 & 28.83 & 28.44 & 27.98 & 28.50 & 29.42 & 28.78 & 28.46 & 30.95 & 32.17 & 32.40 & 33.01 & 30.68 & 32.13 & 32.39 & 32.71 & 33.30 & 33.33 \\
\hline LUX & 10.03 & 9.28 & 10.69 & 10.80 & 11.27 & 12.81 & 10.82 & 10.30 & 10.49 & 10.61 & 9.53 & 10.03 & 9.88 & 10.49 & 10.09 & 9.43 & 8.45 & 8.51 & 9.50 \\
\hline NED & & & & & & & & & 2.19 & 2.29 & 1.92 & 2.35 & 2.83 & 3.56 & 3.36 & 3.21 & 3.73 & 4.13 & 4.13 \\
\hline NEZ & 9.07 & 8.9 & 8.4 & 8.86 & 8.64 & 7.7 & 7.0 & 7.3 & 6.29 & 6.51 & 7.18 & 7.00 & 6.67 & 7.19 & 6.79 & 6.93 & 6.80 & 6.99 & 7.18 \\
\hline NOR & & & & & & & & & 30.45 & 31.18 & 31.51 & 31.48 & 31.40 & 31.06 & 29.18 & 24.75 & 23.96 & 24.62 & 24.51 \\
\hline POR & 0.00 & 0.00 & 0.00 & 0.00 & 0.00 & 0.00 & 0.00 & 0.00 & 0.00 & 0.00 & 0.00 & 0.00 & 0.35 & 0.39 & 0.33 & 0.32 & 0.31 & 0.27 & 0.30 \\
\hline SPA & & & & & & & & & 4.84 & 5.07 & 5.33 & 6.08 & 7.74 & 7.85 & 9.20 & 5.94 & 5.68 & 10.11 & 10.04 \\
\hline SWE & 30.77 & 32.45 & 32.81 & 33.04 & 33.49 & 34.59 & 34.59 & 35.93 & 36.40 & 37.64 & 36.31 & 36.95 & 38.32 & 41.47 & 42.85 & 44.80 & 45.61 & 44.62 & 43.31 \\
\hline SWI & 54.33 & 52.41 & 55.16 & 54.10 & 55.57 & 54.97 & 56.22 & 55.21 & 59.01 & 59.01 & 61.50 & 58.17 & 59.87 & 58.60 & 59.99 & 58.66 & 58.68 & 57.68 & 58.41 \\
\hline UK & 13.77 & 13.80 & 13.0 & 12.4 & 11.56 & 11.41 & 12.41 & 13.7 & 14.25 & 13.02 & 13.56 & 13.18 & 13.03 & 12.94 & 13.28 & 13.04 & 13.90 & 14.07 & 13.45 \\
\hline \multirow[t]{2}{*}{ USA } & 34.38 & 34.62 & 34.41 & 34.56 & 33.42 & 34.80 & 36.55 & 37.31 & 38.12 & 37.31 & 38.30 & 38.40 & 38.00 & 37.48 & 36.29 & 35.64 & 33.91 & 34.72 & 36.26 \\
\hline & 1984 & 1985 & 1986 & 1987 & 1988 & 1989 & 1990 & 1991 & 1992 & 1993 & 1994 & 1995 & 1996 & 1997 & 1998 & 1999 & 2000 & 2001 & \\
\hline AUS & 18.64 & 18.55 & 18.50 & 19.10 & 19.78 & 19.83 & 20.50 & 22.4 & 23.40 & 24.23 & 22.88 & 22.47 & 22.45 & 22.31 & 21.33 & 21.05 & & 17.16 & \\
\hline AUT & 3.45 & 331 & 3.34 & 3.45 & -0 & 66 & 358 & 24 & 3.41 & 3.53 & 3.59 & 3.76 & 3.45 & 3.39 & 4.03 & 3.50 & 2.96 & & \\
\hline BEL & 7.06 & 6.8 & 6.98 & 6.9 & & 7.54 & 3.5 & 19.8 & 20.71 & 21.36 & 22.02 & 23.61 & 23.78 & 24.27 & 24.34 & 24.55 & & & \\
\hline CAN & 51.98 & 52.44 & 51.26 & 50.65 & 51.78 & 51.62 & 52.70 & 52.90 & 53.53 & 55.36 & 54.64 & 54.66 & 53.86 & 52.25 & 52.86 & 52.20 & 51.57 & 51.65 & \\
\hline DEN & 28.73 & 27.63 & 26.46 & 2803 & 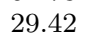 & 2965 & 30.61 & 30.9 & 31.16 & 30.84 & 30.96 & 31.48 & 31.19 & 31.46 & 31.97 & 31.82 & 32.57 & & \\
\hline FIN & 26.07 & 2 & 26.0 & 25.8 ? & 24.88 & 24.30 &. .1 & 26.2 & 26.69 & 31.15 & 32.18 & 29.50 & 8.21 & 25.85 & 25.10 & 24.64 & 22.48 & 25.49 & \\
\hline FRA & 15.21 & 15.59 & 15.6 & 15.5 & 16.16 & 16.28 & 16.85 & 16.89 & 19.05 & 19.81 & 20.05 & 19.96 & 19.93 & 19.65 & 19.53 & 18.74 & 18.01 & & \\
\hline GER & 7.74 & & 7.8 & & & 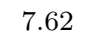 & 78 & & 6.81 & 6.96 & 6.79 & 6.49 & 7.20 & 765 & 7.61 & 7.47 & 7.29 & 6.87 & \\
\hline GRE & 0. & 0 . & 0.0 & & & 0.3 & 0 & 0. & 0.21 & 0.19 & 0.17 & 0.19 & 0.17 & 0.17 & 0.24 & 0.27 & 0.25 & & \\
\hline ICL & 19.34 & 19.05 & 18.73 & 19.20 & 20.01 & 20.41 & 20.52 & 21.69 & 22.29 & 22.54 & 21.62 & 22.17 & 21.60 & 25.69 & 24.95 & 24.80 & 24.86 & 26.39 & \\
\hline IRL & 2.56 & 2.72 & 2.71 & & & 307 & 30 & 26 & 2.94 & 2.87 & 2.76 & 2.8 & 2.66 & 246 & 2.33 & 2.14 & 2.11 & 2.26 & \\
\hline ITA & 0.43 & 0.42 & & & & & & & 1.31 & 5.32 & 5. & 5.23 & 5.67 & 5.90 & 6.19 & 5.86 & 13.74 & 14.12 & \\
\hline JAP & 33.53 & 34.07 & 33.1 & 33.18 & 33.44 & 32.74 & 31.79 & 32.68 & 34.34 & 33.69 & 33.72 & 34.13 & 35.00 & 35.17 & 37.54 & 37.68 & 37.00 & 37.91 & \\
\hline LU & & & 9. & & & 9.2 & & & 7. & 8. & 7. & 9. & 8.91 & & 8. & 7.79 & 7.84 & 8.14 & \\
\hline NED & 4. & 4. & 3. & & & & & & 3. & 3.4 & 4. & 4.73 & 5.02 & 5.19 & 5.20 & 5.12 & 5.05 & & \\
\hline NEZ & 6.6 & & 6.0 & & & 5. & 5 & 6. & 5.33 & 5.45 & 5.31 & 5.17 & 5.51 & 5.29 & 5.77 & 6.19 & 6.05 & 5.53 & \\
\hline NOR & 23. & 23. & 24.7 & 2 & & 28 & 27. & 27. & 27.78 & 27.53 & 27.47 & 25.53 & 24.74 & 23.53 & 23.44 & 23.45 & 20.53 & 20.15 & \\
\hline POR & 0.42 & 0 & 0. & 0. & & 1.76 & & 2. & 2.61 & 2.85 & 2.68 & 2.85 & 2.92 & 2.89 & 3.14 & 3.36 & 3.18 & & \\
\hline SPA & 12.66 & 11.8 & 8.1 & & 7. & 7.25 & 8.1 & 7. & 11.32 & 12.09 & 12.50 & 12.69 & 12.86 & 21.98 & 23.07 & 22.55 & 22.26 & 22.12 & \\
\hline SWE & & & 38.0 & 35.74 & 37.16 & 38.2 & 40. & 43.5 & 47.41 & 47.56 & 46.41 & 47.02 & 46.26 & 44.28 & 43.45 & 41.12 & 42.57 & 44.65 & \\
\hline SWI & 57.31 & 57.06 & 55.49 & 56.61 & 55. & 56.29 & 55.34 & 55.78 & 55.69 & 58.67 & 57.12 & 56.99 & 55.67 & 55.14 & 52.52 & 54.54 & 51.55 & & \\
\hline UK & 17 & 12.8 & 13.5 & 14.04 & 13.86 & 13.75 & & & 5.28 & 5.20 & 5.04 & 4.88 & 4.77 & 4.81 & 4.76 & 4.98 & 4.82 & 5.07 & \\
\hline USA & 37.54 & 37.52 & 38.03 & 37.64 & 38.33 & 37.98 & 38.15 & 38.55 & 39.08 & 39.03 & 38.81 & 38.58 & 37.84 & 37.00 & 36.18 & 35.92 & 34.99 & 35.88 & \\
\hline
\end{tabular}

Note: Only including autonomous own tax revenue of sub-national governments (indicator TDec1). 
Table 12: Degree of revenue decentralization, OECD countries, annual figures, 1975-2001

\begin{tabular}{|c|c|c|c|c|c|c|c|c|c|c|c|c|c|c|}
\hline & 1975 & 1976 & 1977 & $\begin{array}{l}1978 \\
\end{array}$ & 1979 & 1980 & 1981 & 1982 & 1983 & 1984 & 1985 & 1986 & $\begin{array}{l}1987 \\
\end{array}$ & 1988 \\
\hline AUS & 23.86 & 23.66 & 24.11 & 24.20 & 23.51 & 22.96 & 23.10 & 24.18 & 25.18 & 24.29 & 24.95 & 25.48 & 25.53 & 26.74 \\
\hline AUT & 13.42 & 13.28 & 13.26 & 13.10 & 12.99 & 13.78 & 13.85 & 14.29 & 14.71 & 14.04 & 13.87 & 13.58 & 14.00 & 14.55 \\
\hline BEL & & & & 7.23 & 7.34 & 6.69 & 6.55 & 7.19 & 7.24 & 7.97 & 7.88 & 8.07 & 8.16 & 8.03 \\
\hline CAN & & & & & 54.66 & 53.46 & 51.47 & 53.55 & 54.62 & 53.61 & 54.43 & 53.24 & 52.82 & 54.55 \\
\hline DEN & 31.90 & 31.48 & 32.14 & 31.07 & 31.27 & 30.40 & 30.84 & 31.39 & 31.69 & 30.04 & 29.09 & 27.92 & 29.30 & 30.49 \\
\hline FIN & 33.51 & 32.41 & 33.46 & 33.28 & 32.02 & 31.38 & 31.10 & 31.48 & 31.62 & 31.44 & 32.02 & 30.78 & 30.65 & 30.42 \\
\hline FRA & & & & 6.15 & 6.13 & 14.67 & 14.66 & 14.82 & 15.64 & 17.76 & 18.26 & 19.21 & 19.31 & 19.86 \\
\hline $\begin{array}{l}\text { GER } \\
\text { GRE }\end{array}$ & 21.70 & 21.96 & 21.53 & 21.44 & 21.06 & 21.67 & 21.85 & 21.91 & 22.41 & 22.12 & 21.92 & 21.98 & 21.91 & 22.44 \\
\hline ICL & 18.95 & & & & & 22.97 & 22.70 & 22.70 & 19.16 & 20.22 & 20.31 & 19.85 & 20.60 & 21.18 \\
\hline IRL & 14.79 & 14.04 & 14.00 & 11.91 & 11.90 & 10.67 & 10.01 & 9.02 & 9.10 & 9.43 & 10.13 & 10.17 & 10.41 & 9.53 \\
\hline ITA & & & & & & & & & & & 6.25 & 6.15 & 5.24 & 5.31 \\
\hline JAP & & & & & & & & & & & & & & \\
\hline LUX & 10.33 & 10.37 & 10.79 & 11.12 & 10.93 & 10.07 & 9.13 & 9.82 & 10.52 & 9.77 & 10.03 & 10.22 & 9.41 & 9.28 \\
\hline NED & 7.06 & 7.66 & 8.16 & 8.98 & 9.00 & 8.71 & 9.29 & 9.93 & 10.44 & 10.62 & 10.64 & 10.00 & 10.51 & 9.89 \\
\hline NEZ & & & & 11.99 & 11.18 & 11.25 & 11.17 & & & & & & & \\
\hline NOR & & & & & & 27.15 & 26.58 & 26.70 & 25.34 & 24.99 & 24.61 & 25.59 & 27.61 & 28.71 \\
\hline POR & & & & & & & & & & & & & 4.13 & 4.46 \\
\hline SPA & & & 11.77 & 11.79 & 11.55 & 10.36 & 9.96 & 13.50 & 14.00 & 15.23 & 16.90 & 13.01 & 11.69 & 11.92 \\
\hline SWE & & & & 42.86 & 43.90 & 45.86 & 46.63 & 45.21 & 43.83 & 43.71 & 41.65 & 38.70 & 36.05 & 37.50 \\
\hline SWI & 64.69 & 62.52 & 64.18 & 63.51 & 64.68 & 63.81 & 63.97 & 63.30 & 64.04 & 63.31 & & & & \\
\hline UK & 20.04 & 17.90 & 18.53 & 18.45 & 18.77 & 18.45 & 19.33 & 19.81 & 18.52 & 17.99 & 17.53 & 18.31 & 18.79 & 19.33 \\
\hline USA & & & & & & 41.08 & 39.63 & 40.73 & 42.31 & 43.75 & 44.00 & 45.34 & 45.33 & 45.85 \\
\hline & 1989 & 1990 & 1991 & $\begin{array}{l}1992 \\
\end{array}$ & 1993 & 1994 & 1995 & $\begin{array}{l}1996 \\
\end{array}$ & 1997 & 1998 & 1999 & 2000 & 2001 & \\
\hline AUS & 27.77 & 28.56 & 31.25 & 32.27 & 32.94 & 31.93 & 31.70 & 31.82 & 32.03 & 31.79 & 30.80 & & & \\
\hline AUT & 14.94 & 14.66 & 15.08 & 15.08 & 15.64 & 15.89 & 17.66 & 16.16 & 13.00 & 13.95 & 13.21 & & & \\
\hline BEL & 18.04 & 18.88 & 20.42 & 20.99 & 21.34 & 22.12 & 23.95 & 24.13 & 25.03 & 24.96 & & & & \\
\hline CAN & 54.56 & 55.58 & 55.54 & 56.30 & 58.18 & 57.95 & 57.87 & 57.17 & 56.20 & & 56.57 & 56.99 & 56.39 & \\
\hline DEN & 30.61 & 31.39 & 31.08 & 31.16 & 30.43 & 30.94 & 31.94 & 31.66 & 32.04 & 32.41 & 32.52 & 32.83 & & \\
\hline FIN & 30.01 & 31.96 & 33.41 & 34.70 & 32.33 & 33.07 & 33.74 & 32.63 & 31.37 & 29.95 & & & & \\
\hline FRA & 20.03 & 20.40 & 20.42 & 22.47 & 23.24 & 23.68 & 23.58 & 23.34 & 22.79 & & & & & \\
\hline GER & 21.57 & 22.13 & 20.89 & 20.35 & 20.42 & 19.86 & 20.72 & 20.85 & & & & & & \\
\hline GRE & & & & & & & & & & & & & & \\
\hline ICL & 21.49 & 21.55 & 22.84 & 23.21 & 23.75 & 23.01 & 23.55 & 23.47 & 26.66 & 26.19 & & & & \\
\hline IRL & 10.15 & 10.07 & 9.49 & 9.39 & 9.51 & 9.80 & 9.68 & 9.82 & 9.08 & & & & & \\
\hline ITA & 5.98 & & & & & & 8.50 & 9.68 & 9.84 & 9.91 & 10.01 & & & \\
\hline JAP & & & & & & & & & & & & & & \\
\hline LUX & & 13.58 & 13.97 & 12.93 & 13.32 & 12.91 & 13.81 & 13.68 & 12.87 & & & & & \\
\hline NED & 10.41 & 9.64 & 13.25 & 13.01 & 11.87 & 14.70 & 13.88 & 15.66 & 13.70 & & & & & \\
\hline NEZ & & & & 7.25 & 7.56 & 7.57 & 7.54 & 8.27 & 8.66 & 8.78 & 11.74 & 9.68 & 8.13 & \\
\hline NOR & 28.01 & 26.57 & 26.93 & 27.83 & 27.52 & 27.56 & 25.86 & 25.10 & 24.10 & 25.41 & 25.11 & & & \\
\hline POR & 4.99 & 5.00 & 6.33 & 4.94 & 5.35 & 4.99 & 5.19 & 5.46 & 6.04 & 7.38 & & & & \\
\hline SPA & 12.11 & 12.62 & 12.55 & 14.69 & 15.27 & 16.65 & 16.14 & 16.75 & 24.67 & & & & & \\
\hline SWE & 38.29 & 39.69 & 41.69 & 44.62 & 39.89 & 38.94 & 42.87 & 42.01 & 39.67 & 39.65 & 38.53 & & & \\
\hline SWI & & 64.03 & 61.38 & 61.95 & 64.44 & 63.26 & 62.97 & 61.91 & 61.70 & 59.76 & 61.41 & 58.79 & & \\
\hline UK & 19.73 & 13.98 & 10.73 & 10.92 & 11.02 & 10.45 & 9.80 & 9.45 & 9.17 & 9.11 & & & & \\
\hline USA & 45.46 & 46.02 & 46.21 & 47.25 & 46.86 & 46.76 & 46.25 & 46.97 & 46.50 & 46.38 & 46.07 & 45.60 & & \\
\hline
\end{tabular}

Note: Only including autonomous own tax, non-tax and capital revenue of sub-national governments (indicator $R D e c 1$ ). 


\section{References}

Arikan, G. G. (2004), Fiscal decentralization: A remedy for corruption?, International Tax and Public Finance $11,175-195$.

BAHL, R. (1986), The design of intergovernmental transfers in industrialized countries, Public Budgeting $\&$ Finance 6, 3-22.

BAHL, R. (1999), Implementation rules for fiscal decentralization, Andrew Young School of Policy Studies, Georgia State University, unpublished manuscript.

Behnisch, A., Buettner, T. and D. Stegarescu (2002), Public sector centralization and productivity growth: Reviewing the German experience, ZEW Discussion Paper No. 02-03, Mannheim.

BIRD, R. M. (1986), Federal finance in comparative perspective, Toronto.

Blankart, C. B. (1999), Die schleichende Zentralisierung der Staatstätigkeit: Eine Fallstudie, Zeitschrift für Wirtschafts- und Sozialwissenschaften 119, 331-350.

Committee of the Regions (1999), Regional and local democracy in the European Union, Brussels.

Committee of the Regions (2000), Decentralisation of European decision making, Brussels.

Committee of the Regions (2001), Regional and local government in the European Union - Responsibilities and resources, Brussels.

Council of Europe (1997), Federal and regional states, Collection science and technique of democracy, No. 19.

Council of Europe, Structure and operation of local and regional democracy, different country studies, Strasbourg.

Davoodi, H. and H. Zou (1998), Fiscal decentralization and economic growth: A cross-country study, Journal of Urban Economics 43, 244-257.

DöHLER, E. (2002), Autonome Besteuerungsrechte für Gliedstaaten und Gemeinden in ausgewählten föderativen Finanzverfassungen, INFER Research Edition Vol. 7, Berlin.

Ebel, R. D. and S. Yilmaz (2003), On the measurement and impact of fiscal decentralization, in: MartinezVazquez, J. and S. Yilmaz (eds.), Public finance in developing and transitional countries : Essays in honor of Richard Bird, Cheltenham etc., 101-126.

Engel, C. and J. van Ginderachter (1992), Le pouvoir régional et local dans la Communauté Européenne, Études de Droit des Communautés Européennes, Paris.

European Commission (2002), Inventory of taxes in the EU, different country studies, Brussels.

Feld, L. P., Kirchgässner, G. and C. A. Schaltegger (2003), Decentralized taxation and the size of government: Evidence from Swiss state and local governments, CESifo Working Paper No. 1087, Munich.

Fisman, R. and R. Gatti (2002), Decentralization and corruption: evidence across countries, Journal of Public Economics 83(3), 325-345.

Fossati, A. and G. PAnella (eds.) (1999), Fiscal federalism in the European Union, London and New York.

Greene, W. H. (2000), Econometric analysis, 4th ed., Prentice Hall.

International Monetary Fund (IMF) (2001), Government Finance Statistics Manual, Washington.

Kaufman, H. (1963), Politics and policies in state and local governments, Englewood Cliffs (NJ).

Kraus, A. (1983), Zentrale und dezentrale Tendenzen im Föderalismus, Göttingen.

Levin, J. (1990), Measuring the role of subnational governments, in: Prud'homme, R. (Ed.), Public finance with several levels of government, Proceedings of the 46th Congress of the IIPF, Brussels, 21-36.

LiJPhart, A. (1984), Democracies, New Haven and London.

Majone, G. (1997), From the positive to the regulatory state: Causes and consequences of changes in the mode of governance, Journal of Public Policy 17, 139-167.

MiÑAnA, J.-S. (1998), Décentralisation, corresponsabilité et responsabilité fiscales: Étude de dix-huit États européens, Cahiers économiques de Bruxelles, No. 160(4), 389-425. 
Norton, A. (1994), International handbook of local and regional government - A comparative analysis of advanced democracies, Aldershot and Brookfield.

OAtes, W. E. (1972), Fiscal federalism, New York etc.

OAtes, W. E. (1985), Searching for Leviathan: An empirical study, American Economic Review 75(4), 748-757.

OECD (1997), Managing across levels of government, Paris.

OECD (1999), Taxing powers of state and local government, OECD Tax Policy Studies No. 1, Paris.

OECD (2002a), Fiscal design surveys across levels of government, OECD Tax Policy Studies No. 7, Paris.

OECD (2002b), Fiscal decentralization in EU applicant states and selected EU member states, Report prepared for the workshop on "Decentralization: trends, perspective and issues at the threshold of EU enlargement, Denmark, October 10-11, 2002.

OECD (2003), OECD Economic Outlook 74, Paris.

Owens, J. P. and J. NorRegaArd (1991), The role of intermediate and local levels of government: the experience of selected OECD countries, in: King, D. N. and J. P. Owens (eds.), Fiscal federalism in economies in transition, proceedings of a conference organised by the OECD, April 1991, 69-116.

PAnizzA, U. (1999), On the determinants of fiscal centralization: Theory and evidence, Journal of Public Economics 74, 97-139.

Patsouratis, V. A. (1990), Fiscal decentralization in the EEC countries, Public Finances / Finances Publiques $45(3), 423-439$.

PolA, G. (1999), A comparative view of local finances in EU member countries: are there any lessons to be drawn?, in: Fossati, A. and G. Panella (eds.), Fiscal federalism in the European Union, London and New York, 15-62.

Pommerehne, W. W. (1977), Quantitative aspects of federalism: A study of six countries, in: Oates, W. E. (ed.), The political economy of fiscal federalism, Lexington (MA).

Rahmann, B., Steinborn, U. and G. Vornholz (1994), Empirische Analyse der Autonomie lokaler Finanzwirtschaften in der Europäischen Gemeinschaft, Finanzwissenschaftliche Schriften 64, Frankfurt a. M., etc.

Schaltegger, C. A. and L. P. Feld (2001), On government centralization and budget referendums: Evidence from Switzerland, CESifo Working Paper No. 615, Munich.

Sharpe, L. J. (1979), Decentralist trends in western democracies, London and Beverly Hills.

Sмiтн, B. C. (1979), The measurement of decentralization, International Review of Administrative Sciences 1 , $214-222$

Stephens, G. (1974), State centralization and the erosion of local autonomy, Journal of Politics 36(1), 44-76.

Ter-Minassian, T. (ed.) (1997), Fiscal federalism in theory and practice, International Monetary Fund, Washington.

Thiessen, U. (2003), Fiscal decentralisation and economic growth in high-income OECD countries, Fiscal Studies 24(3), 237-274.

Treisman, D. (2002), Defining and measuring decentralization: A global perspective, unpublished manuscript.

Wallis, J. J. and W. E. OAtes (1988), Decentralization in the public sector: An empirical study of state and local government, in: Rosen, H. S. (ed.), Fiscal federalism: Quantitative studies, The University of Chicago Press.

Wasylenko, M. (1987), Fiscal decentralization and economic development, Public Budgeting ES Finance 7(4), $57-71$.

Zimmermann, H. (1973), Die Ausgabenintensität der öffentlichen Aufgabenerfüllung. Finanzarchiv N.F. 32(1), $1-20$. 